\title{
Öğretmen Adaylarının Özel Eğitim ve Kaynaştırma Eğitiminde Matematik Uygulamalarına İlişkin Görüşleri
}

\author{
Yrd. Doç. Dr. Mihriban HACISALIHHOĞLU-KARADENİ**
}

Giresun Üniversitesi, Eğitim Fakültesi, Matematik Eğitimi, Giresun / Türkiye

\section{$\ddot{\mathbf{O} z}$}

Çalışmanın amacı; matematik öğretmeni adaylarının "Özel Eğitim” dersinden beklentilerine ve kaynaştırma eğitiminde matematik uygulamalarına ilişkin kazanımlarını ve süreçte karşılaştıkları problemleri ortaya çıkarmaktır. Böylelikle bu dersin ve kaynaştırma eğitiminde matematik uygulamalarının hizmet öncesinde öğretmenlik yeterliliklerine katkısının belirlenmesine firsat verilmesi mümkün olacaktır. Çalışma, Giresun Üniversitesi Eğitim Fakültesi Matematik Eğitimi ABD'nin son sınıfında öğrenim gören ve "Özel Eğitim" dersini alan 54 matematik öğretmeni adayı ile yürütülmüştür. Nitel bir durum çalışması olan araştırmanın verileri anket yoluyla toplanmıştır. Bu çalışma kapsamındaki veriler, nitel veri analiz yöntemlerinden içerik ve betimsel analiz yöntemleri kullanılarak analiz edilmiştir. Çalışma sonunda elde edilen bulgulara göre, "Özel Ĕgitim" dersinin, öğretmen adaylarına olumlu katkıları olduğu ve kaynaştırma eğitiminde matematik uygulamalarına ilişkinse; öğrenci ve aileleriyle iletişim kurmayı, sabırlı, hoşgörülü ve duyarlı olmayı sağladığı ortaya çıkmıştır. Katılımcıların tamamına yakını bu dersin; özel gereksinimli öğrenci ve kaynaştırma uygulamalarının yapısının kavranmasında kolaylık sağladığı, bu tür çocuklara yönelik

\footnotetext{
* Sorumlu Yazar. Tel: +90 $5535955861 \quad$ E-posta: mihrideniz61@ gmail.com $\quad$ ORCID: 0000-0002-7836-6868
}

(C) 2017 Kalem Eğitim ve Sağlık Hizmetleri Vakfı. Bütün Hakları Saklıdır. ISSN: 2146-5606 
farkındalıklarının ve hassasiyetlerinin arttığı, çok faydalanacakları bilişsel ve duyuşsal yeni öğrenmeler elde ettikleri ve bu öğrendiklerinin kendilerine mesleki deneyim kazandırarak öğretmenlik yeterliliklerine katkıda bulunduğunu düşündükleri ortaya çıkmıştır. Ayrıca adayların pek çoğu "Özel Eğitim" dersini kuramsal bilgi edinmenin yanı sıra kaynaştırma öğrencileriyle uygulama yapmaktan büyük bir memnuniyet duyduklarını ifade etmişlerdir.

Anahtar Kelimeler: Özel eğitim; Özel gereksinimli öğrenci; Kaynaştırma eğitiminde matematik uygulamaları; Matematik öğretmeni adayı.

\title{
Opinions of Preservice Teachers about Special Education Course and Mathematical Applications in Inclusive Education
}

\begin{abstract}
The purpose of this study is to determine the expectations of the preservice mathematics teachers with the "Special Education", their attainments regarding mathematical applications in the inclusive education and problems they encounter in this process. In this way, the contributions of this course and mathematical applications in the inclusive education to the preservice teaching competencies might be determined. The present study was conducted with 54 preservice mathematics teachers who were senior students studying in the Department of Mathematics Teaching in the Faculty of Education of Giresun University. Data of the research which is a qualitative case study were collected through questionnaires. Data of the study were analysed through content analysis and descriptive analysis methods which are qualitative data analysis methods. According to the findings of the study, "Special Education" course positively contributes to the preservice teachers and, as for the mathematical applications in inclusive education, they allow for communication with students and their families and being patient, tolerant and sensitive. Almost all of the participants expressed that this course helped them understand children with special needs and comprehend the structure of the inclusive applications; increased awareness and sensitivity levels towards these children; enabled them to gain new cognitive and affective attainments that they will greatly benefit from; and what they learned from this course provided them with professional experiences and contributed to their teaching competencies. Also, most of the preservice teachers stated that they were satisfied with the opportunity of gaining theoretical information and of carrying out appli-
\end{abstract}


cations with the inclusive students thanks to the "Special Education" course.

Keywords: Special education; Students with special needs; Mathematical applications in inclusive education; Preservice mathematics teachers.

\section{Extended Summary}

\section{Purpose}

Although the importance of inclusive education has recently been understood in Turkey, the number of studies on special education and mathematical applications in inclusive education, in particular, is limited. Thus, the need to carry out this study has emerged. The lack in the literature in this respect is striking and assessing whether the mathematical applications reach their goals during inclusive education is of great importance. In this regard, the present study was conducted in order to present the expectations of the participants about the "Special Education" course, their attainments from the mathematical applications in the inclusive education and the problems they experience in this process.

\section{Method}

The present study was conducted with 54 preservice teachers who were senior students studying in the department of Mathematics Teaching in the Faculty of Education in Giresun University and received the "Special Education" course. Data of this research which is a qualitative case study were collected through questionnaires. "Questionnaire Form on Special Education Course" consisting of 6 open end questions was used in order to determine the opinions of preservice teachers about their expectations from and recommendations for the course while "Questionnaire Form on Mathematical Applications in Inclusive Education" consisting of 7 open end questions was used in order to determine the opinions of the participants about mathematical applications in inclusive education. Data of the present study were analysed through content analysis and descriptive analysis methods which are qualitative analysis methods.

\section{Results}

The findings obtained from the study indicated that the "Special Education" course positively contributed to the preservice teachers and, as for the mathematical applications in inclusive education, they helped participants to 
communicate with the students and their families and to be patient, tolerant and sensitive. It was also emphasized in the findings that conducting activities, using materials and varying teaching methods/techniques and preparing "Individualised Education Program" and "Individualised Teaching Program" in accordance with the educational performances of the students in the mathematical applications of inclusive education were useful. It was concluded that the participants listed preparing activities, finding solutions for potential problems, gaining experience, being patient and tolerant, detecting deficiencies, being sensitive, being knowledgeable, gaining individual benefits, not ignoring individual differences and acquiring a new perspective among the benefits of mathematical applications performed with inclusive students.

\section{Discussion}

Participants listed their expectations from the "Special Education" course as being able to communicate with students with special needs, learning how to approach these students and integrating them into the society and rehearsing for teaching while reporting the difficulties experienced during the course as dealing with the procedure $(60 \%)$ and lack of support from executives and teachers in the school (40\%). This result can be clearly seen in the study of Pınar-Sazak and Yıkmış (2004) as well. Participants specified the difficulties they experienced during the mathematical applications performed with the inclusive students as confusion about banknotes and preparing activities and materials for the special education applications while it was concluded that no difficulties were experienced in communication with these students. As for the use of materials by the participants during the applications, it was concluded that most of the teachers did not use materials (Hacısalihoğlu-Karadeniz, Akar and Şen, 2015). However, it was emphasized in the study conducted by Salend and Duhaney (1999) that the teachers should be provided with support for cooperation in terms of instructional and physical resources, using strategies, time, preparing and applying instruction program and evaluation. The study of Mcleskey and Waldron (2002) presented similar findings as well. As for the benefits that the "Special Education" course offers, the participants stated that the course contributed to their teaching competencies by enabling them to communicate with the students with special needs, to gain awareness about special education (McLeskey, Waldron, So, Swanson and Loveland, 2001) and to acquire professional 
experiences.

\section{Conclusion}

Participants specified the difficulties they experienced during the mathematical applications performed with the inclusive students as confusion about the coins and preparing activities and materials for the special education applications while it was concluded that no difficulties were experienced in communication with these students. Participants listed 'relations among assets' and 'number patterns' in the unit of "Algebra"; 'rhythmic numerations', 'four operations in natural numbers', 'fractions' and 'natural numbers' in the unit of "Numbers and Operations" in the applications performed with inclusive students. It was also concluded that they tried to teach such subjects as 'basic geometrical concepts', 'geometrical objects', 'triangle and quadrangle', 'pattern' and 'polygonal regions' in the unit of 'Geometry' and such subjects as 'banknotes', 'length-mass-time-space measurement' and 'weighing' in the unit of 'Measurement'. Almost all of the participants stated that this course contributed to their professional competencies by helping them understand students with special needs and comprehend the structure of inclusive applications, increasing awareness and sensitivity levels towards such children, providing them with new cognitive and affective attainments as well as professional experiences.

\section{Giriş}

Özel gereksinimli bireylerin bulundukları sosyal çevrenin bir parçası olarak hayatlarını sürdürebilmek için eğitimde firsat eşitliğinden yararlanmaları gerekmektedir. Bu bireylerin eğitiminde; bireylerin engeline bağlı olarak geliştirilen program çerçevesinde yapılan 'ayrı eğitim', özel gereksinimli ve normal bireylerin sınıf ortamında, sınıf öğretmenleri ve özel eğitim uzmanları ile birlikte yürütülen 'birlikte eğitim' olarak uygulanmaktadır (Batu, Kircaali-İftar ve Uzuner, 2004; Batu ve Kircaali-İftar, 2007). Bunlardan 'birlikte eğitim' uygulaması, özel gereksinimli öğrencinin normal sınıfta eğitilmesi temeline dayanan kaynaştırma uygulamaları (Kargın, 2004; Kırcaali-İftar, 1997) son yıllarda sıklıkla kullanılan bir uygulamadır. Kaynaştırma uygulamaları; özel gereksinimli öğrencilerin eğitimlerini destek eğitim hizmetleri de sağlanarak normal gelişim gösteren akranları ile birlikte tam ya da yarı zamanlı olarak sürdürebilmeleri esasına dayanan bir özel eğitim uygulaması olarak kabul edilmektedir (Millî Eğitim Bakanlığı [MEB], 2006; 
Gürgür, 2008). Türkiye'de 573 Say1lı Kanun Hükmünde Kararnâme’de “Özel Eğitim Hizmetleri Yönetmeliğinde" kaynaştırma uygulamalarının zorunlu hâle getirildiği açıkça ifade edilmektedir (Sucuoğlu, 2004; Sucuoğlu ve Kargın, 2006).

Bütün dünyada ve Türkiye'de öğrenci gereksinimlerinin farkındalığ1nın artması ve önemsenmesi, öğrencinin programa dayalı gereksinimlerinin belirlenmesi, etkili eğitim-öğretim sunulması, aile katılımı, destekleyici özel eğitim hizmetlerinin sağlanması kaynaştırma uygulamalarında vazgeçilmezleridir (Batu, 2008; Özokçu, 2013). Kaynaştırma uygulamalarının ögelerini; öğretmenler, yöneticiler, ebeveynler, normal gelişim gösteren akranlar ve özel gereksinimli ögrenciler olarak sayabiliriz (Batu, 2000). Siralanan bu ögeler, öğrencinin gereksinimlerini karşılamaya yönelik programlar hazırlanması ya da var olan programların öğrencinin gereksinimlerine göre uyarlanması, etkili öğretim yöntem ve tekniklerinin kullanılması, etkili sınıf yönetimi ve gerekli destek hizmetlerin sağlanması olarak karşımıza çıkmaktadır (Smith, Polloway, Patton ve Dowdy, 2006). Bu durum, kurumda görev yapan bütün bireylere, özellikle öğretmenlere önemli roller ve sorumluluklar yüklemektedir. Öğretmenin bu duruma uyum sağlayabilmesi için özel eğitim ve kaynaştırma uygulamaları konusunda yeterli bilgiye sâhip olacak düzeyde yetiştirilmesi gerekmektedir. Öğretmenlerin kaynaştırma ve özel eğitim konusunda bilgilerinin eksik olduğu, yeterli deneyimlerinin olmadığı (Babaoğlan ve Y1lmaz, 2010; Berry, 2011; Demir ve Açar, 2011) açıkça görülmektedir. $\mathrm{Bu}$ bağlamda kaynaştırma uygulamalarının başarılı olmasında en önemli etkenin öğretmen olduğu düşünülürse, öğretmenin bu konudaki donamı süreci başarıya ulaştırır (Batu, 2000). Diken (1998) çalışmasında, sınıfında zihin engelli çocuk bulunan ve bulunmayan sınıf öğretmenlerinin zihin engelli öğrencilerin kaynaştırılmasına yönelik tutumlarını karşılaştırmış, öğretmenlerin çok az bir kısmının sınıfında kaynaştırma öğrencisi olmasını gönüllü olarak istedikleri; diğer öğretmenlerin ise gönüllü olmadıkları sonucuna ulaşmıştır. Dolayısıyla sınıf öğretmeninin daha önce hiç duymadığı ve görmediği özellikteki bir öğrenci hakkında hazırlık yapması hayatî önem taş1maktadır. Dolayısıyla öğretmen adayları hizmet öncesinde bu konudaki farkındalıklarının artırılması ve bilgilendirme çalışmalarının yapılması gerekmektedir.

Özel gereksinimli öğrencilerin normal öğrencilerin sınıf ortamında, 
sınıf öğretmenleri ve özel eğitim uzmanları ile birlikte yürüttükleri 'birlikte eğitim' alması, akranları ile etkileşim hâlinde olması bu öğrencilerin sosyal becerilerinin geliştirilmesini sağlamaktadır (Maag, 2005). Ancak özel gereksinimli öğrencilerin sosyal becerilerinin geliştirilmesi yanında akademik becerilerinin geliştirilmesi için de öğretmenlerin hizmet öncesinde bu konuda donanımlı olması ön şart kabul edilmelidir. YÖK tarafından 2006-2007 akademik yılından itibaren öğretmen yetiştirme programlarında bütün bölümlerde "Özel Ĕgitim" dersi uygulamaya konmuştur. Bununla birlikte Türkiye'deki öğretmen yetiştiren lisans programları incelendiğinde, öğretmen adaylarının özel eğitim konusunda kuramsal bilgiyle donatıldıkları ve özel gereksinimli öğrencilere matematik becerileri kazandırmak adına gerekli eğitimi almadıkları, dolayısıyla bu konuda eksiklerinin olduğu açıkça görülmektedir. Oysa özel gereksinimli öğrencilerin devam ettikleri okullarda sosyal becerilerinin (Maag, 2005; Sazak-Pınar, Sucuoğlu ve Çıkrıkçı-Demirtaşl1, 2013) yanı sıra akademik becerilerinin de desteklenmesi ve akademik başarılarının artırılması adına adımlar atılması gerekir (Hacısalihoğlu-Karadeniz, Akar ve Şen, 2015). Bu bağlamda öğretmen adaylarının özel gereksinimli öğrencilerin akademik becerilerini geliştirmeyi daha iyi algıladıkları, kaynaştırmaya yönelik kaygılarının azaldığı (Shippen, Crites, Houchins, Ramsey ve Simon, 2005) ve özel eğitim konusunda bilgilendirilmenin adayların olumlu tutum sergilemesine yol açtığını ortaya koymuşlardır (Gözün ve Yıkmış, 2004). Bu nedenle adaylara, lisans döneminde verilen "Özel Eğitim" dersinde kuramsal bilginin yanı sıra kaynaştırma eğitiminde matematik uygulamalarına ilişkin farkındalık kazandırmak, böylelikle öğretmenlik yeterliliklerine katkı sağlamak önemli görülmektedir.

Özel gereksinimli öğrenciler sınıflarında, öğretim programlarında yer alan ve normal gelişim gösteren öğrencilere göre düzenlenmiş derslerle ve öğretim programlarıyla karşı karşıya kalmaktadırlar (MEB, 2000). Matematik dersi ve matematik öğretim programı da bunlardan biridir. Matematik kavram ve becerilerinin kazandırılmasında yaşanan bazı zorluklar göz önüne alınırsa bu öğrencilere uygun öğretim programların plânlanması üstünde önemle durulması gereken bir konudur. Öğretmenlerin, özel gereksinimli öğrencilere sınıf düzeylerinin altında matematik öğretmesi ve alt sınıfların programına uyarlama yapması (Yönter, 2009; Hacısalihoğlu-Karadeniz, 2013) oldukça dikkat çekicidir. 
Matematik kavram ve becerileri kazanmanın gündelik hayatı sürdürebilmedeki önemi dikkate alınırsa, matematik öğretiminin özel gereksinimli öğrencilere göre düzenlenmesi ve onların gereksinimleri doğrultusunda bireyselleştirilerek sunulması hayatî önem taşımaktadır (Hudson ve Miller, 2006). Öğretmenler, özel gereksinimli öğrencilere matematiğin en temel konusu olan sayma becerilerini kazandırabilmek ve matematik kavramlarına ön koşul öğrenmeler oluşturmak için de bu becerilere gereken önemi vermeli ve uygun öğretim yöntemlerini kullanmalıdırlar (Alptekin, 2015). Özellikle matematik, gündelik hayatta farkında bile olmadan kullandığımız bir ders olmaktan öteye bir hayat biçimidir (Hacısalihoğlu-Karadeniz, 2013). Dolayısıyla matematik dersinin bu özellikleri, özel gereksinimli öğrencilerin akademik becerilerinin gelişmesinde, öğrenim hayatına devam etmesinde, öğrenimini tamamlamasında, eğitsel performansına ve engeline uygun bir meslek sahibi olmasında etkili olabilmektedir. Ancak özel gereksinimli öğrenciler, kaynaştırma ortamında çeşitli nedenlerle matematik dersinin olumlu etkilerinden yeterince faydalanamamaktadırlar. $\mathrm{Bu}$ nedenlerin en önemlisi matematik öğretmeni adaylarının hizmet öncesinde farklı ihtiyaçları ve gereksinimleri olan öğrenciler konusunda bilgilendirilmemiş oldukları düşünülmektedir.

Kaynaştırma eğitimi Türkiye'de de son yıllarda öneminin anlaşılmasına rağmen öğretmen adaylarının özel eğitim ve özellikle de kaynaştırma eğitiminde matematik uygulamalarına ilişkin yeteri kadar çalışmaya rastlanmaması da çalı̧̧manın yapılma ihtiyacını gündeme getirmiştir. Alanyazında bu konuda bir boşluğun olduğu göze çarpmakta ve matematik uygulamalarının kaynaştırma eğitimi sürecinde amacına ulaşıp ulaşmadığımı değerlendirmek önemli görülmektedir. Bu durumda öğretmen adaylarının görüşleri alınarak; özel eğitim dersine ilişkin beklentilerini, kaynaştırma eğitiminde matematik uygulamalarına ilişkin kazanımlarını ve süreçte karş1laştıkları problemleri ortaya çıkartmak amaçlanmıştır. Böylelikle "Özel Ĕgitim" dersinin ve kaynaştırma eğitiminde matematik uygulamalarının hizmet öncesinde öğretmenlik yeterliliklerine katkısının belirlenmesine firsat verilmesi mümkün olacaktır. 


\section{Yöntem}

Bu bölümde; araştırmanın deseni, çalışma grubu, veri toplama araçları, verilerin analizi, uygulama süreci ve sınırlılıklar ile ilgili bilgiler yer almaktadir.

\section{Araştırma Deseni}

Araştırmalarda nitel yöntem kullanılmasının sebebi, yöntemin araştırmacılara inceledikleri olguyu derinlemesine kavramalarına imkân sağlamasıdır (Patton, 2002). Nitel araştırma yöntemi, genellikle, kişilerin deneyim sâhibi oldukları olaylara ilişkin algılarını keşfetmek için kullanılmaktadır (Bogdan ve Biklen, 2003; Denzin ve Lincoln, 2000). Araştırma sorularının doğası irdelemeyi gerektiriyor ise özellikle nitel araştırma yöntemi kullanılmalıdır (Stake, 1995). Bu çalışma, nitel araştırma yaklaşımı kullanılarak yürütülmüştür. Nitel araştırmalar; doğal ortama duyarlılık sağlama, bütüncül bir yaklaşıma sâhip olma, algıların ortaya konması, araştırma deseninde esneklik ve tümevarımcı bir analize sâhip olma gibi önemli özellikleri içinde barındırmaktadır (Yıldırım ve Şimşek, 2011). Bu özellikler dikkate alınarak, ilgili araştırma nitel olarak tasarlanmıştır.

\section{Katılımcılar}

$\mathrm{Bu}$ araştırmanın katılımcılarını, Giresun Üniversitesi Eğitim Fakültesi Matematik Eğitimi ABD'nin son sınıfında öğrenim gören ve "Özel Ĕgitim” dersini alan 54 matematik öğretmeni adayı oluşturmaktadır. Çalışmaya katılan öğretmen adayları araştırma etiği çerçevesinde; "K1, K2, K3, K4, K5, ... , K54" şeklinde kodlanmıştır.

\section{Verilerin Toplama Aracı}

Çalışmada adayların, "Özel Eğitim" dersinden beklenti ve önerilerine ilişkin görüşlerini belirlemek amacıyla 6 açık uçlu sorudan oluşan "Özel Eğitim Dersine İlişkin Anket Formu” kullanılmıştır. İlgili birinci formda adayların; derse yönelik görüşleri, dersten beklentileri, dersin işleniş sürecinde karşılaştıkları zorluklar, dersin kendilerine sağlayacağı faydalar, göreve başladığında bu dersten öğrendiklerini uygulamayı düşünüp-düşünmediği, dersinin etkili ve verimli yürütülmesine ilişkin görüşlerinin neler olduğunun açığa çıkarılmasına çalışılmıştır.

Öğretmen adaylarının kaynaştırma eğitiminde matematik uygulamala- 
rına ilişkin görüşlerini belirlemek amacıyla da 7 açık uçlu sorudan oluşan; "Kaynaştırma Ĕgitiminde Matematik Uygulamalarına İlişkin Anket Formu" kullanılmıştır. İlgili ikinci formda adayların; kaynaştırma eğitimi uygulaması öncesi hazırlıklara, kaynaştırma öğrencilerine matematik öğretilebilmesine, uygulamada öğretilen ünite/konuya ve kullanılan yöntem/tekniklere, dersin öğrenme sürecinde karşılaşılan güçlüklere, bu uygulamaların katkılarına, göreve başladığında sınıfında kaynaştırma öğrencisi bulunursa onlara matematik öğretmeyi düşünmesine ilişkin görüşlerinin neler olduğunun açığa çıkarılmasına çalışılmıştır. Ayrıca araştırmacı tarafından geliştirilen açık uçlu sorulardan oluşan formların geçerliliğini sağlamak için üç alan eğitimi uzmanından görüş alınmıştır.

\section{Verilerin Analizi}

$\mathrm{Bu}$ çalışma kapsamındaki veriler, içerik ve betimsel analiz yöntemleri birlikte kullanılarak analiz edilmiştir. Toplanan veriler Word belgesi olarak kaydedildikten sonra öğretmen adaylarının sorulara verdikleri cevaplar, içerik analizi yapılarak tema ve kodlar oluşturulmuştur. Daha sonra, kodların frekans ve yüzde değerleri hesaplanmıştır. Bazı katılımcılar açık uçlu soruları yanıtlarken aynı cevap içerisinde birden fazla temaya ilişkin görüş bildirdiğinden, bazı sorulara ise cevap vermediklerinden temalara ilişkin kodlara verilen frekansların toplamı, araştırmaya katılan toplam katılımcı sayısından farklı olabilmektedir.

Nitel bir araştırmada; toplanan verilerin ayrıntılı olarak rapor edilmesi, bireylerden doğrudan alıntılara yer verilmesi ve bunlardan yola çıkarak sonuçların açıklanması araştırmanın geçerliğinin sağlanması açısından oldukça önemlidir (Yıldırım ve Şimşek, 2011). Bu nedenle, bu araştırmada araştırma süreci ayrıntılı bir şekilde ele alınmış ve betimsel analiz çerçevesinde doğrudan alıntılara yer verilmiştir.

\section{Uygulama Süreci}

"Özel Ĕ̆itim" dersini alan öğretmen adayları dönemin altınc1 haftasında, ilgili dersin öğretim elemanı ile birlikte Millî Eğitim Bakanlığı Özel Öğretim Kurumları Genel Müdürlüğü tarafından 2008 yılında hazırlanan "Matematik Kaba Değerlendirme-MKDF" formundan yararlanarak uygulamaya karar verdikleri öğretimsel amaçları belirlemişlerdir (MEB, 2008). Öğretimsel amaçların belirlenmesinde, özel gereksinimli öğrencilerin eğitsel 
performans düzeyine uygun olmasına dikkat edilerek günlük plânlar hazırlanmıştır. Öğretmen adayları, yedinci hafta ise günlük ders plânı raporlarını sınıfta grup çalışmasıyla sunmuşlardır. Çalışma kapsamında adaylardan matematik öğretim programı ve MKDF'den seçtikleri öğretimsel amaçlara uygun "Bireyselleştirilmiş Ĕ̈itim Programı-BEP”, "Bireyselleştirilmiş Öğretim Programı-BÖP" ve günlük plan hazırlamaları istenmiştir. Her hafta yürütülen ders saati içerisinde öğretmen adaylarından grup çalışması şeklinde BEP, BÖP, günlük plân ve tasarladıkları materyal raporlarını sunmaları istenmiştir. Öğretmen adaylarının raporları incelenerek bir sonraki derste uygulamaların işleyişi ile ilgili geri bildirimler verilmiştir. Adaylar, "Okul Deneyimi” için gittikleri okullarda yaptıkları gözlemler sonucunda belirledikleri kaynaştırma öğrencilerine, hazırladıkları raporları uygulamaya çalışmışlardır.

Uygulamalar tamamlandıktan sonra veri toplama aracı olarak açık uçlu sorulardan oluşan iki formdan yararlanılmıştır. Araştırmacı tarafından geliştirilen açık uçlu sorulardan oluşan formların geçerliliğini sağlamak için üç alan eğitimi uzmanından görüş alınmıştır. Açık uçlu formlar, 54 öğretmen adayına uygulanmıştır. Form uygulanan öğretmen adaylarından; “Özel Ĕgitim" dersinden beklentilerine ve kaynaştırma eğitiminde matematik uygulamalarına ilişkin kazanımlarını ve süreçte karşılaştıkları problemleri açıkça ifade etmeleri istenmiştir.

\section{Sinırlılıklar}

Çalışmanın ikinci bölümünde yürütülen uygulamalar, 'birlikte eğitim' uygulamas1 sürecinde "özel eğitim hizmeti" ya da "destek eğitim hizmeti" alan öğrencileri kapsamaktadır.

\section{Bulgular}

Bulgular iki bölümden oluşmaktadır. Birinci bölümde öğretmen adaylarının "Özel Eğitim” dersine ilişkin görüşleri, ikinci bölümde ise kaynaştırma eğitiminde matematik uygulamalarına ilişkin düşünceleri yer almıştır. Her iki bölümdeki tablolar sırasıyla aşağıda verilmiştir:

\section{Öğretmen Adaylarının “Özel Eğitim” Dersine İlişkin Görüşleri}

Tablo 1'e göre katılımcıların "Özel Eğitim" dersinin amaçlarına ilişkin görüşleri; "duyuşsal", "bireysel” ve "ders" teması olmak üzere üç tema altında toplanmıştır: 
Katılımcılar, "Duyuşsal" teması altında \%71'i farkındalık sağlama, \%29'u empati yapma şeklinde görüş belirtmişlerdir. "Bireysel” teması altında \%43.3'ü topluma kazandırma, \%40.1'i gündelik hayata uyum sağlama, \%13.3'ü öz bakım becerilerini kazanma, \%3.3'ü kendi gereksinimlerini karş1lama şeklinde görüş belirtmişlerdir. "Ders" teması altında \%39.1'i eğitimde firsat eşitliğinin sağlanması, \%21.7'si öğrenciyi tanıma, \%17,3'ü öğrenciye ders anlatma, \%8.6's1 yol izleme, \%4.3'ü bilgi sâhibi olma, \%4.3'ü özel eğitimin amacını öğrenme ve \%4.3'ü yöntem ve teknik öğrenme şeklinde görüş belirtmişlerdir.

Tablo 1. "Özel Eğitim” Dersinin Amaçlarına İlişkin Öğretmen Adaylarının Görüşleri

\begin{tabular}{llll}
\hline & & f & \% \\
\hline Duyuşsal & Farkındalık sağlama & 12 & 71 \\
& Empati yapma & 5 & 29 \\
\hline Bireysel & Topluma kazandırma & 13 & 43.3 \\
& Gündelik hayata uyum sağlama & 12 & 40.1 \\
& Öz bakım becerileri kazanma & 4 & 13.3 \\
& Kendi gereksinimlerini karşılama & 1 & 3.3 \\
\hline Ders & Eğitimde firsat eşitliğininin sağlanması & 9 & 39.1 \\
& Öğrenciyi tanıma & 5 & 21.7 \\
& Öğrenciye ders anlatma & 4 & 17.3 \\
& Yol izleme & 2 & 8.6 \\
& Bilgi sâhibi olma & 1 & 4.3 \\
& Özel eğitimin amacını öğrenme & 1 & 4.3 \\
& Yöntem ve teknik öğrenme & 1 & 4.3 \\
\hline
\end{tabular}

K57, K3 ve K29 kodlu katılımcılar “Özel Eğitim” dersinin amaçlarına yönelik görüşleri şu ifadelerle açıklamışlardır:

"Özel gereksinimli ögrencilere nasıl davranılmasl gerektiğini ve bu konuda ne gibi zorluklarla karşllaşabileceğimizi öğretmek, öğretmen adaylarının bu derste özel gereksinimli ögrencilerle ilgili bilgiler edinerek farkındalıklarinin artırlması." (K57)

"Özel eğitim dersinin amaçları, özel gereksinime ihtiyacı olan, görme, duyma engeli bulunan, öğrenme güçlüğ̈̈ olan bireylerin topluma kazandırılmasıdır. Bu bireylerin temel ihtiyaçlarını karşılayabilecek hâle 
gelmelerini ve toplumda dışlanmayıp bir yerlere gelebilmelerini să̆lamaya çalışılır." (K3)

"Her öğrencinin eğitim hakkı vardır. Bireysel yaklaşım esastır. Erken tedavi çok önemlidir. Ekip çalışması esastır. Eğitime aile mutlaka katılmalıdır. Kaynaştırma temel ilke olmalıdır. ” (K29)

Tablo 2. "Özel Eğitim” Dersinden Beklentilere İlişkin Öğretmen Adayı Görüşleri

\begin{tabular}{llll}
\hline & & $\mathbf{f}$ & $\mathbf{\%}$ \\
\hline İletişim & Bireyleri topluma kazandırma & 3 & 42.8 \\
& Öğrenci ile iletişim kurma & 3 & 42.8 \\
& Gözlem yapma & 1 & 14.4 \\
\hline Duyuşsal & Öğrenciye yaklaşma & 19 & 61.3 \\
& Farkındalık kazanma & 8 & 25.8 \\
& Empati kurma & 4 & 12.9 \\
\hline Ders & Öğretmenlik provası yapma & 17 & 50 \\
& Dersin içeriğini öğrenme & 6 & 17.6 \\
& BEP hazırlama & 3 & 8.8 \\
& KPSS ye hazırlanma & 2 & 5.9 \\
& Dersi geçme & 2 & 5.9 \\
& Zayıf yönleri tamamlayabilme & 2 & 5.9 \\
& Öğrenciyle birlikte çalışma & 1 & 2.9 \\
& Ders hakkında bilgi sâhibi olunmaması & 1 & 2.9 \\
\hline
\end{tabular}

Tablo 2'ye göre öğretmen adaylarının "Özel Eğitim” dersinden beklentilerine yönelik görüşleri; "iletişim", "duyuşsal" ve "ders" teması olmak üzere üç tema altında toplanmıştır.

Katılımcılar, "İletişim" teması altında \%42.8'i bireyleri topluma kazandırma, \%42.8'i öğrenci ile iletişim kurma, \%14.4'ü gözlem yapma şeklinde görüş belirtmişlerdir. "Duyuşsal" teması altında \%61.3'ü öğrenciye yaklaşma, \%25.8'i farkındalık kazanma ve \%12.9'u empati kurma şeklinde görüş belirtmişlerdir. "Ders" temas1 altında \%50'si öğretmenlik provas1 yapma, \%17.6'sı dersin içeriğini öğrenme, \%8.8'i BEP hazırlama, \%5.9'u KPSS'ye hazırlanma, \%5.9'u dersi geçme, \%5.9'u zayıf yönlerini tamamlayabilme, \%2.9'u öğrenciyle birlikte çalışma ve \%2.9'u ders hakkında bilgi sâhibi olunması şeklinde görüş belirtmişlerdir. 
K7, K37 ve K28 kodlu katılımc1lar "Özel Eğitim” dersinden beklentilerinize yönelik görüşleri şu ifadelerle açıklamışlardır:

"Özel eğitim dersini daha çok teorik yürüteceğimizi düşünüyordum. Fakat dersi almaya başlayınca ögrenciyle daha aktif olarak iletişime girerek olaylara bakış açım daha da değişti." (K7)

"Özel eğitim dersinden beklentilerim, özel gereksinimli öğrenciyi anlayabilmek onunla empati kurabilmekti. Bu beklentilerime fazlasiyla ulaştığımı düşünüyorum. Bu dersi almadan önce dersin ne olduğunu dahi bilmiyordum; ama şuan özel gereksinimli bir öğrenciye dokunmak, onu anlamaya çalışmak çok güzel ve mutluluk verici." (K37)

“....Beklentilerimiz karşıladık; çünkü artı öğretmen olduğumuz zaman kaynaştırma öğrencileri ile nasl hareket edeceğimiz hakkinda bütün bilgilere ulaştık (yapılması gerekenlere)." (K28)

Tablo 3. “Özel Eğitim” Dersinin İşleniş Sürecine (Öğrenme Süreci) ve Dersin İşleniş Sürecinde Karşılaştıkları Güçlüklere İlişkin Öğretmen Adayı Görüşleri

\begin{tabular}{llll}
\hline & & f & $\mathbf{\%}$ \\
\hline Yönetim & Prosedür ile uğraşma & 3 & 60 \\
& Okuldaki yönetici ve öğretmenlerden destek görememe & 2 & 40 \\
\hline İletişim & Bir zorluk ile karşılaş1lmamıştır & 17 & 73.9 \\
& Kaynaştırma öğrencisiyle iletişim kurma & 5 & 21.7 \\
& Öğrenci bulmada zorlanma & 1 & 4.4 \\
\hline \multirow{2}{*}{ Uygulama } & Ödev yapmada zorlanma & 26 & 74.2 \\
& Uygulama yaparken zorlanma & 4 & 11.4 \\
& Etkinlik hazırlamada & 3 & 8.6 \\
& Materyal hazırlamada & 1 & 2.8 \\
& Derste drama yapma & 1 & 2.8 \\
\hline
\end{tabular}

Tablo 3'e göre katılımcıların “Özel Eğitim” dersinin işleniş sürecine (öğrenme süreci) ilişkin ve dersin işleniş sürecinde karşılaştıkları güçlükler hakkındaki görüşleri; "yönetim", "iletişim" ve "uygulama" teması olmak üzere üç tema altında toplanmıştır:

Katılımc1lar, "Yönetim" teması altında; \%60’1 prosedür ile uğraşma ve \%40'i okuldaki yönetici ve öğretmenlerden destek görememe şeklinde görüş belirtmişlerdir. "İletişim” teması altında; \%73.9'u zorluk ile karşılaşmamıştır, \%21.7'si kaynaştırma öğrencisiyle iletişim kurma, \%4.4'ü öğrenci 
bulmada zorlanma şeklinde görüş belirtmişlerdir. "Uygulama" teması altında; \%74.2'si ödev yapmada zorlanma, \%11.4'ü uygulama yaparken zorlanma \%8.6's1 etkinlik hazırlamada, \%2.8'i materyal hazırlamada ve \%2.8'i derste drama yapmada zorlanma şeklinde görüş belirtmişlerdir.

K11, K16 ve K43 kodlu öğretmen adayları “Özel Eğitim” dersinden beklentilerinize yönelik görüşleri şu ifadelerle açıklamışlardır:

"Özel eğitim ilk başlarda uzak olduğumuz bir alandı ve ne yapmamı gerektiğini bilmiyorduk. Öğrencilere nasıl yaklaşacă̆ız, ne gibi etkinlikler yapacağız veya resmi evrakları nasıl dolduracă̆ı. Zamanla bunlar hakkında bilgi edindik ve neler yapmamız gerektiğini öğrendik." (K11)

“...Ödev aşamasında ögrrenciye ulaşmakta zorluk yaşadım ne kadar derste bir şeyler öğrenmiş olsak da iletişim kurarken öğrenci gerek cevap vermek istemedi, gerek slkıldı ve bazen zor durumda kaldım." (K16)

"Aslında en başta BEP ve BÖP hazırlarken, kaba değerlendirme formlarin yaparken, ögrenciyle etkinlik yapmak hepsi beni korkuttu. Biraz, çocukla iletişim nasıl kuracağım, nasıl bir etkinlik yapacağım gibi birçok şey... Ama yaptıktan sonra hele çocukla iletişimimiz de olumlu geçince çok mutlu iyi ki zorlanmışım da ögrenmişim dedim." (K43)

Tablo 4. "Özel Eğitim” Dersinin Kendilerine Sağladığı/Sağlayacağ1 Faydalara İlişkin Öğretmen Adayı Görüşleri

\begin{tabular}{llll}
\hline & & f & $\mathbf{\%}$ \\
\hline İletişim & İletişim kurma & 17 & 100 \\
\hline Duyuşsal & Farkındalık sağlama & 16 & 69.5 \\
& Empati yapma & 7 & 30.5 \\
\hline \multirow{2}{*}{ Ders } & Meslek hayatına hazırlanma & 28 & 63,6 \\
& Dersin içeriğini öğrenme & 13 & 29.5 \\
& Eğitimde firsat eşitliği & 3 & 6,8 \\
\hline
\end{tabular}

Tablo 4'e göre öğretmen adaylarının "Özel Eğitim” dersinin kendilerine sağladığı/sağlayacağı faydalara yönelik görüşleri; "iletişim”, "duyuşsal” ve "ders" teması olmak üzere üç tema altında toplanmıştır: 
Katılımcıların tamamı "İletişim” teması altında özel gereksinimli öğrencilerle iletişim kurmak istediklerini belirtmişlerdir. "Duyuşsal" teması altında \%69.5'i farkındalık sağlama ve \%30.5'i empati yapma şeklinde görüş belirtmişlerdir. "Ders" teması altında \%63.6'sı meslek hayatına hazırlanma, $\% 29.5$ 'i dersin içeriğini öğrenme ve \%6.8'i eğitimde firsat eşitliği şeklinde görüş belirtmişlerdir.

K6, K15 ve K13 kodlu öğretmen adayları “Özel Eğitim” dersinin size sağladığı/sağlayacağ1 faydalara yönelik görüşlerini şu ifadelerle açıklamışlardır:

"Özel eğitim dersi meslekî olarak bana çok şey kattı. Sinıfimda olan özel gereksinimli ögrencileri nasıl fark edeceğimi, sonraki adımlarla onlara nasıl davranmam gerektiğini öğrendim. Bu öğrencilerin unutulmamass ve yardım edilmesi konusunda farkindallk kazandım. Meslek hayatımda okuldaki boş saatlerimde kaynaşttrma öğrencileriyle destek odasında onlara zaman ayıracağım. " (K6)

"Bireysel olarak farkındalık. Akademik olarak firsat eşitliği. Zaten her ikisi önce insanoğlunun sonra ögretmenlerinin karakterinde olmast gereken özellikler.” (K15)

"Eğitim hayatımda kaynaştırma öğrencisiyle karşılaş̧tı̆ım vakit ona nasil bir eğitim verebileceğim konusunda meslekî anlamda bilgilendim. Bireysel olarak bilgi dağarcı̆̆ıma yeni kavramlar ekledim. Örneğin; özel eğitim, kaynaştırma, BEP, RAM, diskalkuli, disleksi, disgrafi vb." (K13)

Öğretmen adaylarının göreve başladıklarında "Özel Ĕgitim” dersinde öğrendiklerini uygulamayı düşünmesi hakkındaki görüşleri; "evet/hayır”, "duyuşsal" ve "eğitim" teması olmak üzere üç tema altında toplanmıştır.

Katılımcıların "Evet/Hayır" teması altında tamamının derste öğrendiklerini uygulamayı düşündüklerini belirtmişlerdir. "Duyuşsal" teması altında \%60'1 empati kurma ve \%40’1 farkındalık yaratma şeklinde görüş belirtmişlerdir. "Eğitim" teması altında \%31'i topluma uyum sağlayan birey yetiştirme, \%25.8'i firsat eşitliği, \%25.8'i faydalı bilgileri kullanma, \%15.5'i mesleği yerine getirme ve \%1.8'i erken teşhis şeklinde görüş belirtmişlerdir. 
Tablo 5. Göreve Başladıklarında "Özel Eğitim” Dersinde Öğrendiklerini Uygulamayı Düşünmesine İlişkin Öğretmen Adayı Görüşleri

\begin{tabular}{llll}
\hline & & $\mathbf{f}$ & \% \\
\hline Evet / & Evet & 68 & 100 \\
Hayır & & & \\
\hline Duyuşsal & Empati kurma & 6 & 60 \\
& Farkındalık yaratma & 4 & 40 \\
\hline Eğitim & Topluma uyum sağlayan birey yetiştirme & 18 & 31 \\
& Firsat eşitliği & 15 & 25.8 \\
& Faydalı bilgiler kullanma & 15 & 25.8 \\
& Mesleği yerine getirme & 9 & 15.5 \\
& Erken teşhis etme & 1 & 1.8 \\
\hline
\end{tabular}

K28 ve K29 kodlu katılımcılar göreve başladıklarında "Özel Eğitim" dersinde öğrendiklerini uygulamayı düşünmeyle ilgili görüşleri şu ifadelerle açıklamışlardır:

"Tabii ki de kaynaştırma öğrencisi varsa uygulamayı düşünüyorum. Zaten düşünmem değil uygulamam gerekir. Çünkü bizde öyle olabilirdik; çünkü bunun için kendi yaşamına devam ettirebilmesi için elimizden geleni sonuna kadar yapmamız gerekir." (K28)

"Kesinlikle uygulamamı gereken programdır. Her birey eşittir, her bireyin eğitime ihtiyacl vardır. Elimden gelenin en iyisini yapmaya çalışırım." (K29)

Tablo 6' da öğretmen adaylarının "Özel Eğitim” dersini etkili ve verimli yürütülmesine ilişkin görüşleri; “öneri”, “zaman”, “öğretim yöntemi” ve "uygulama" teması olmak üzere dört tema altında toplanmıştır.

Katılımc1lar; “Öneri” teması altında \%100'ü öneri yoktur şeklinde görüş belirtmişlerdir. "Zaman” teması altında \%100'ü zaman artırılması şeklinde görüş belirtmişlerdir. "Öğretim Yöntemi” teması altında \%42.8'i drama tekniğinin kullanılması, \%42.8'i materyal kullanılmalı ve \%14.4'ü mikro öğretim yapılmalı şeklinde görüş belirtmişlerdir. "Uygulama" teması altında \%56.4'ü grup çalışmasıyla uygulaması yapılması, $\% 12.8$ ' $\mathrm{i}$ iş birliğinin yapılması, \%7.7'si rehabilitasyon merkezlerine gidilmeli, \%7.7'si seminer verilmeli, \%5'i birlikte etkinlik yapılmalı, \%2.6'sı kaynaştırma öğrencisi ile daha fazla ilgilenilmeli, \%2.6's1 öğretmenlerle görüşme yapma, \%2.6's1 
gözlemler artırılmalı ve \%2.6'sı bilgilendirme yapılmalı şeklinde görüş belirtmişlerdir.

Tablo 6. "Özel Eğitim” Dersinin Etkili ve Verimli Yürütülmesine İlişkin Öğretmen Adayı Görüşleri

\begin{tabular}{llll}
\hline & & f & \% \\
\hline Öneri & Yoktur & 21 & 100 \\
\hline Zaman & Zamanın artırılması & 7 & 100 \\
\hline Öğretim & Drama tekniğinin kullanılması & 3 & 42.8 \\
yöntemi & Materyal kullanılmalı & 3 & 42.8 \\
& Mikro öğretim yapıllmalı & 1 & 14.4 \\
\hline Uygulama & Grup çalı̧masıyla uygulaması yapılması & 22 & 56.4 \\
& İş birliğinin yapılması & 5 & 12.8 \\
& Rehabilitasyon merkezlerine gidilmeli & 3 & 7.7 \\
& Seminer verilmeli & 3 & 7.7 \\
& Birlikte etkinlik yapılmalı & 2 & 5 \\
& Kaynaştırma öğrencileri ile daha fazla ilgilenmeli & 1 & 2.6 \\
& Öğretmenlerle görüşme yapma & 1 & 2.6 \\
& Gözlemler artırılmalı & 1 & 2.6 \\
& Bilgilendirme yapılmalı & 1 & 2.6 \\
\hline
\end{tabular}

K24, K28, K16 ve K6 kodlu kat1lımcılar "Özel Eğitim” dersinin etkili ve verimli yürütülmesi hakkında görüşlerine yönelik şu ifadelerle açıklamışlardir:

"Bu sene için bizim için farklı bir ders oldu ve hüzünlü aynı zamanda keyifliydi. Hocamız bu dersin ne kadar önemli olduğunu bize gösterdi. Bence gayet verimliydi bunun üzerine daha bir şey yapılacă̆ını düşünmüyorum." (K24)

"Bence tek döneme sığmamalı ve "Öğretmenlik Uygulaması" dersinin olduğu ikinci dönemde verilmeli, böylece uygulamalar daha rahat yapllır. Öğretmen olacak bireyler için çok önemli olduğunu düşünüyorum. Çünkü ulu önderimiz Atatürk'ün de dediği gibi yeni nesil bizim eserimiz olacaktır." (K28)

"Sinıfta yaptığımız dramalar ve etkinlikler dersi daha etkili kıldı. Dersin sunumlarla işlenmesi de farklı arkadaşlarımızın kattıkları yorumlar ile verimli oldu. Benim daha etkili ve verimli olmast için bunun üstünde bir önerim yok." (K16) 
"Gayet etkili ve verimli yürüdügünü düşünüyorum. Zaman olsaydl uygulamalar çoğaltılabilir sadece." (K6)

\section{Öğretmen Adaylarının Kaynaştırma Eğitiminde Matematik Uy- gulamalarına İlişkin Görüşleri}

Tablo 7. Okullarda Yapılan Kaynaştırma Eğitiminde Matematik Uygulamasına Gitmeden Önce Yapılan Hazırlık Aşamalarına İlişkin Öğretmen Adayı Görüşleri

\begin{tabular}{llll}
\hline & & f & \% \\
\hline Özel eğitim raporları & BEP hazırlama & 23 & 28.8 \\
& Etkinlik hazırlama & 22 & 27.7 \\
& MKDF kullanma & 18 & 22.5 \\
& BÖP hazırlama & 17 & 21 \\
\hline Özel eğitim & Materyal hazırlama & 16 & 51.6 \\
uygulamaları & Ders Planı hazırlama & 9 & 29 \\
& Teknik belirleme & 3 & 9.7 \\
& Öğretimsel amaçları belirleme & 1 & 3.2 \\
& Yöntem belirleme & 1 & 3.2 \\
& Pekiştireç belirleme & 1 & 3.2 \\
\hline
\end{tabular}

Tablo 7'e göre öğretmen adaylarının okullarda yaptığınız matematik uygulamasına gitmeden önce yapılan hazırlık aşamalarına ilişkin; "özel eğitim raporları" ve "özel eğitim uygulaması" teması olmak üzere iki tema altında toplanmıştır:

Katılımc1lar; "Özel Eğitim Raporları” teması altında \%28.8'i BEP hazırlama, \%27.7'si etkinlik hazırlama, \%22.5'i MKDF kullanma ve \%21'i BÖP hazırlama şeklinde görüş belirtmişlerdir. "Özel Eğitim Uygulaması" temas1 altında \%51.6's1 materyal hazırlama, \%29'u ders planı hazırlama, \%9.7'si teknik belirleme, \%3.2'si öğretimsel amaçları belirleme, \%3.2'si yöntem belirleme ve \%3.2'si pekiştireç belirleme şeklinde görüş belirtmişlerdir.

K40 ve K47 kodlu öğretmen adayları okullarda yaptığınız matematik uygulamasına gitmeden önce hazırlık aşamaları hakkında yönelik görüşleri şu ifadelerle açıklamışlardır: "Önce öğrenciyi tanıdım. Hazır bulunuşluğuna baktım. Daha sonra MKDF yardımıla BEP ve BÖP hazırladım.” (K40), 
"Öğrencinin ĕgitsel performansina uygun etkinlikler tasarladım, buldum. Materyal hazırladım." (K47)

Tablo 8. Kaynaştırma Öğrencilerine Matematik Öğretilebilmesine ve Okullarda Yapılan Uygulamada Kaynaştırma Öğrencilerine Matematik Öğretiminde Öğretilen Ünite/Konuya İlişkin Öğretmen Adayı Görüşleri

\begin{tabular}{llll}
\hline & & $\mathrm{f}$ & $\mathbf{\%}$ \\
\hline Evet/ & Evet & 52 & 98.2 \\
Hayır & Hayır & 1 & 1.8 \\
\hline Cebir & Varlıklar Arasındaki ilişkiler & 2 & 66.7 \\
& Sayı örüntüleri & 1 & 33.3 \\
\hline Sayıllar ve & Ritmik saymalar & 15 & 50 \\
İşlemler & Dört işlem & 7 & 23.3 \\
& Kesirler & 5 & 16.7 \\
& Doğal Sayılar & 3 & 10 \\
\hline Geometri & Temel Geometrik Kavramlar & 9 & 36 \\
& Geometrik cisimler & 7 & 28 \\
& Üçgen ve dörtgen & 5 & 20 \\
& Örüntü & 3 & 12 \\
& Çokgensel bölgeler & 1 & 4 \\
\hline Ölçme & Kütle ölçme & 18 & 50 \\
& Paralarımız & 10 & 27.8 \\
& Uzunluk ölçme & 4 & 11.1 \\
& Zaman ölçme & 2 & 5.6 \\
& Alan ölçme & 1 & 2.7 \\
& Tartma & 1 & 2.7 \\
\hline
\end{tabular}

Tablo 8'e göre katılımcıların, kaynaştırma öğrencilerine matematik öğretilebilmesine ve okullarda yapılan uygulamada öğrencilere hangi ünite/konu öğrettiklerine dair görüşleri; "Evet/Hayır" ve "Cebir", "Sayılar ve İşlemler", "Geometri”, "Ölçme" teması olmak üzere beş tema altında toplanmıştır.

Kat1lımc1lar; "Evet/Hayır" temas1 altında; \%98.2'si 'evet', \%1.8'i 'hayır' şeklinde görüş belirtmişlerdir. "Cebir” teması altında: \%66.7'si 'varlıklar arasındaki ilişkiler' ve \%33.3'ü 'sayı örüntüleri' şeklinde görüş belirtmişlerdir. Katılımcılar; "Sayılar ve İşlemler" teması altında; \%50'si 'ritmik saymalar', \%23.3'ü 'doğal sayılarda dört işlem', \%16.7'si 'kesirler' ve \%10’u 'doğal sayılar' şeklinde görüş belirtmişlerdir. "Geometri” teması altında; \%36's1 'temel geometrik kavramlar', \%28'i 'geometrik cisimler', \%20'si 'üçgen ve dörtgen', \%12'si 'örüntü’ ve \%4'ü 'çokgensel bölgeler' şeklinde 
görüş belirtmişlerdir. "Ölçme” teması altında; \%50'si 'kütle ölçme', \%27.8'i 'paralarımız', \%11.1'i 'uzunluk ölçme', \%5.6's1 'zaman ölçme', \%2.7'si 'alan ölçme' ve \%2.7'si 'tartma' şeklinde görüş belirtmişlerdir. Katılımc1lardan; K3, K36, K19, K23 ve K10, kaynaştırma öğrencilerine matematik öğretebilme ve okullarda yapılan uygulamalarda matematik öğretiminde hangi ünite/konu öğrettiklerine dâir görüşlerini şu ifadelerle açıklamışlardır:

"Evet. Kesinlikle her öğrenciye matematik öğretilebilir. Çünkü her ögrenciye uygun bir yöntem vardır. Önemli olan çocuğu iyi tanımak ve ona göre öğretmek. Mesela ben temel geometrik kavramları hazırladim." (K3)

"Tabii ki ögrretilebilir. Matematik günlük yaşamda çok karş̧laş̧tı̆̆ bir durum. Mesela 'Varliklar Arasındaki Ilisskiler' konusu benim uygulama konumdu." (K36)

"Kaynaştırma öğrencisine daha basit günlük hayatta kullanabileceği düzeyde matematik ögretilmesi gerekir. Mesela; sayllar konusunda ritmik sayllar." (K19)

"Tabii ki öğretilebilir. Kaynaştırma öğrencileri öğrenemeyen değil; öğrenme güçlügüne sâhip bireylerdir. Eğitimde firsat eşitliğini de göz önünde bulundurursak, ögretilebilir. Benim uzun dönemli amacım 'Geometri', kısa dönemli amaç 'Karenin özeliklerini bilir.' ve 'Karenin dörtkenarl olduğunu gösterir/söyler.' öğretimsel amacını uyguladım. Gayet iyi öğrendi." (K23)

"Elbette öğretilir. Fakat ögrenmeleri akran gruplarından yavaş olduğundan biraz daha sinırlı kalır. Benim uygulamam, 'Parayl tanır' kisa dönemli amaca yönelikti. MKDF'den seçtiğim; 'Belirtilen parayı gösterir.' ve 'Gösterilen paranın kaç lira olduğunu söyler.' öğretimsel amacı üzerinde bir çalışma gerçekleştirdim. Siranın üzerine kâğıt paraları koydum ve gerekli sorularl sordum. Biraz zorlandı ama parayı sevdiği için güzel öğrendi." (K10)

Tablo 9'a göre katılımcıların okullarda yapılan uygulamaya göre; kaynaştırma öğrencilerine matematik derslerinde hangi yöntem-teknikleri kullandıklarına dair görüşleri "Öğretim Yöntem/Teknikler” teması altında toplanmıştır. 
Tablo 9. Okullarda Yapılan Uygulamada Kaynaştırma Öğrencilerine Matematik Derslerinde Kullanılan Yöntem/Tekniklere İlişkin Öğretmen Adayı Görüşleri

\begin{tabular}{lll}
\hline Öğretim Yöntem/Teknikler & f & \% \\
\hline Gösterip yaptırma & 36 & 20.3 \\
Soru-cevap & 35 & 19.7 \\
Anlatım & 33 & 18.6 \\
Eğitsel oyun & 21 & 11.8 \\
Drama & 11 & 6.2 \\
Somut model kullanma & 8 & 4.5 \\
Beyin firtınası & 7 & 3.9 \\
Buluş yoluyla öğretim & 6 & 3.4 \\
Sunuş yoluyla & 4 & 2.2 \\
İpucu verme & 4 & 2.2 \\
Ödüllendirme & 3 & 1.7 \\
Tekrar etme & 3 & 1.7 \\
Modelleme yapma & 2 & 1.1 \\
Tartışma & 2 & 1.1 \\
Problem çözme & 1 & 0.56 \\
Şiir & 1 & 0.56 \\
\hline
\end{tabular}

Katılımc1lar; "Öğretim Yöntem/Teknikler" temas1 altında; \%20.3'ü gösterip yaptırma, \%19.7'si soru cevap, \%18.6's1 anlatım, \%11.8'i eğitsel oyun, \%6.2'si drama, \%4.5'i somut model kullanma, \%3.9'u beyin firtınası, \%3.4'ü buluş yolu, \%2.2'si sunuş yolu, \%2.2'si ipucu verme, \%1.7'si ödüllendirme, \%1.7'si tekrar etme, \%1.1'i modelleme yapma, \%1.1'i tartışma, $\% 0.56$ 's problem çözme ve \%0.56'sı şiir yöntem/tekniklerini kullandıklarını belirtmişlerdir.

K31 ve K14 kodlu öğretmen adayları okullarda yaptıkları uygulamaya göre; kaynaştırma öğrencilerine matematik derslerinde hangi yöntem/teknikleri kullandığına dâir görüşlerini şu ifadelerle açıklamışlardır:

"Gösterip Yaptırma: Bir saatin içinde kaç dakika olduğu, yarım saatin kaç dakika olduğu şeklinde saat modeli üzerinde.” (K31)

"Benim kullandığım yöntem/teknikler; soru-cevap, drama, eğitsel oyun. Soru-cevap tekniğini konu anlatımı yaparken kullandım. Hatırlatma ve 
bir somutluk kazanması için. Drama yöntemini bir bölgeyi döşemede kullandım." (K14)

Tablo 10. Kaynaştırma Öğrencileriyle Yapılan Matematik Uygulamasında Matematik Dersinin İşleniş Sürecine (Öğrenme Süreci) ve Öğrenme Sürecinde Karşılaşılan Güçlükler/Zorluklara İlişkin Öğretmen Adayı Görüşleri

\begin{tabular}{llll}
\hline & & $\mathbf{f}$ & $\mathbf{\%}$ \\
\hline Öğrenme & Etkinlik hazırlamada zorlanma & 5 & 62.5 \\
& Paraları karıştırma & 2 & 25 \\
& Materyal eksikliği & 1 & 12.5 \\
\hline Özel Eğitim & Etkinlik uygulama & 23 & 69.7 \\
Uygulamaları & Materyal kullanma & 7 & 21.3 \\
& Çalışma kağıdı kullanma & 1 & 3 \\
& MKDF kullanma & 1 & 3 \\
& Ödüllendirme tekniğini kullanma & 1 & 3 \\
\hline İletişim & Herhangi bir güçlükle karşılaşmama & 7 & 26.9 \\
& Öğrencinin unutkanlığı & 5 & 19.2 \\
& Öğrencinin çekingenliği & 5 & 19.2 \\
& Dikkat dağınıklığı & 4 & 15.4 \\
& Çabuk sikıllabilmesi & 1 & 3.8 \\
& Öğrencinin konuşma güçlüğü & 1 & 3.8 \\
& Hazırbulunuşluğu olmaması & & 3.8 \\
& Kavram karıştırması yaşaması & 1 & 3.8 \\
& İletişim sıkıntısı & 1 & 3.8 \\
& Öğrencinin derse karşı isteksizliği & 1 & 3.8 \\
\hline
\end{tabular}

Tablo 10'a göre öğretmen adaylarının kaynaştırma öğrencileriyle yaptıkları uygulamalarda matematik dersinin işleniş sürecine ilişkin görüşleri; dersin işleniş sürecinde karşılaşılan güçlüklere ilişkin öğretmen adayların görüşleri, "öğrenme", "özel eğitim uygulamaları" ve "iletişim" teması olmak üzere üç tema altında toplanmıştır.

Katılımcılar; "Öğrenme" teması altında: \%62.5'i etkinlik hazırlamada zorlanma, \%25'i paraları karıştırma ve \%12.5'i materyal eksikliği şeklinde görüş belirtmişlerdir. "Özel Eğitim Uygulamaları” teması altında: \%69.7'si etkinlik uygulama, \%21.3'ü materyal kullanma, \%3.3'ü çalışma kâğıdı kullanma, \%3'ü MKDF kullanma ve \%3'ü ödüllendirme tekniğini kullanma 
şeklinde görüş belirtmişlerdir. "İletişim” teması altında \%26.9'u herhangi bir güçlük ile karşılaşmama, \%19.2'si öğrencinin unutkanlığı, \%19.2'si öğrencinin çekingenliği, \%15.4'ü dikkat dağınıklığı, \%3.8'i çabuk sıkılabilmesi, \%3.8'i öğrencinin konuşma güçlüğü, \%3.8'i hazırbulunuşluğunun olmamas1, \%3.8'i kavram karıştırması yaşaması, \%3.8'i iletişim sıkıntısı ve \%3.8'i öğrencinin derse karşı isteksizliği şeklinde görüş belirtmişlerdir.

K1, K3 ve K21 kodlu öğretmen adayları kaynaştırma öğrencileriyle yaptığınız matematik uygulamasında matematik dersinin işleniş sürecine (öğrenme süreci) ilişkin ve dersin işleniş sürecinde karşılaştığınız güçlükler/zorluklara ilişkin görüşleri şu ifadelerle açıklamışlardır:

" 5 E modeli sadeleştirilirse öğrenmede hem zaman ekonomik yönden kullanılmış olur hem de ögrenciye daha basit yapılan etkinliklerle öğrencinin işleniş sürecinden zevk alması ve böylece öğrenmenin gerçekleşmesi de sağlanmuş olur. Öğrencinin çekingenliği ve utangaçlı̆̆ haricinde işleniş sürecinde bir sıkıntı çekmedim." (K1)

"Öğrenciyle tanışma aşamasında onun çok çekindiğini fark ettiğimde yanlış bir davranış sergilemekte endişelendim. Ama onunla konuş̧ukça ve MKDF'yi uygulamaya başladıkça ısındığını fark ettim. Dersin işlenişinde öğrenciye model olarak devam edildiğinde bir güçlükle karşllaşılmadığını fark ettim.” (K3)

"Öğrenciye anlatılan konunun 15 dakika sonra benzer şekilde bir soru sorulduğunda unutması. En çok güçlük çektiğim zorluk.” (K21)

Tablo 11'e göre öğretmen adaylarının kaynaştırma öğrencileri ile yapılan matematik uygulamalarının sağladığı/sağlayacağı faydalara ilişkin görüşleri "özel eğitim uygulamaları" ve "bireysel kazanımlar" teması olmak üzere iki tema altında toplanmıştır.

Kat1lımc1lar; “Özel Eğitim Uygulamaları” temas1 altında; \%78.6's1 etkinlik hazırlama, \%14.3'ü somut materyal tasarlama ve \%7.1'i BEP hazırlama şeklinde görüş belirtmişlerdir. "Bireysel kazanımlar" teması altında; \%40'1 karş1laş1labilecek problemlere çözüm bulma, \%30'u tecrübe sâhibi olma, \%17.5'u gözlem yapma, \%12.5'i sabırlı ve hoşgörülü olma, \%5'i eksiklerini görme, \%5'i duyarlı olma, \%5'i bilgi sâhibi olma, \%2.5'i bireysel yönden kazanç sağlama, \%2.5'i adaletli olma, \%2.5'i bireysel farkl11ıkları göz 
ardı etme ve \%2.5'i farklı bakış açısı şeklinde görüş belirtmişlerdir.

Tablo 11. Kaynaştırma Öğrencileri ile Yapılan Matematik Uygulamalarının Sağladığı/Sağlayacağı Faydalara (Bireysel, Duyuşsal, Akademik, Meslekî vb.) İlişkin Öğretmen Adayı Görüşleri

\begin{tabular}{llcc}
\hline & & $\mathbf{f}$ & \% \\
\hline Özel & Etkinlik hazırlama & 11 & 78.6 \\
Eğitim & Somut materyal tasarlama & 2 & 14.3 \\
Uygulamaları & BEP hazırlama & 1 & 7.1 \\
\hline Bireysel & Karşılaşılabilecek problemlere çözüm bulma & 16 & 40 \\
Kazanımlar & Tecrübe sâhibi olma & 12 & 30 \\
& İletişim kurma & 7 & 17.5 \\
& Sabırlı ve hoşgörülü olma & 5 & 12.5 \\
& Eksiklerini görme & 2 & 5 \\
& Duyarlı olma & 2 & 5 \\
& Bilgi sâhibi olma & 2 & 5 \\
& Bireysel yönden kazanç sağlama & 1 & 2.5 \\
& Adaletli olma & 1 & 2.5 \\
& Bireysel farklılı̆̆ göz ardı etmeme & 1 & 2.5 \\
& Farklı bakış açısı & 1 & 2.5 \\
\hline
\end{tabular}

K34 ve K22 kodlu katılımcılar kaynaştırma öğrencileri ile yapılan matematik uygulamalarının sağladığı/sağlayacağı faydalara yönelik görüşlerini şu ifadelerle açıklamışlardır:

"Okul hayatımda özel gereksinimli bir öğrenci tanışmak ona yardım etmek çok güzel bir duygu. Onunla yaptı̆̆ım etkinlikler sayesinde ileride öyle bir ögrenci karşıma çıktı̆̆ zaman nasıl yöntem/teknikle, hangi etkinlikleri kullanacağımı ve çocuğa nasıl yaklaşacağımı öğrendim." (K34)

"Göreve başladı̆ğmda karşılaşacağım güçlükleri tecrübe etmiş oldum. Korkum ya da kaygım diyelim... azaldı bu sayede." (K22)

Tablo 12'ye göre öğretmen adaylarının kaynaştırma öğrencileriyle yaptıkları matematik uygulamalarının daha etkili ve verimli yürütülmesine ilişkin görüşleri "öneri”, "zaman”, "iletişim” ve "özel eğitim uygulamaları" teması olmak üzere dört tema altında toplanmıştır. 
Tablo 12. Kaynaştırma Öğrencileriyle Yapılan Matematik Uygulamalarının Daha Etkili ve Verimli Yürütülmesine İlişkin Öğretmen Adayı Görüşleri

\begin{tabular}{llcc}
\hline & & f & \% \\
\hline Öneri & Yoktur & 5 & 100 \\
\hline Zaman & Geniş zaman aralığında yapıllması & 12 & 100 \\
\hline İletişim & İletişim kurma & 1 & 33.3 \\
& Açık ve anlaşı1ır anlatım sergileme & 1 & 33.3 \\
& Aile ile iletişim kurulmalı & 1 & 33.3 \\
\hline Özel Eğitim & Etkinlik uygulama & 22 & 46.8 \\
Uygulamaları & Materyal kullanma & 17 & 36.2 \\
& Teknik kullanma & 7 & 14.9 \\
& Düzeye uygun BEP ve BÖP hazırlama & 1 & 2.1 \\
\hline
\end{tabular}

“Öneri” teması altında \%100'ü öneri yoktur şeklinde görüş belirtmişlerdir. Katılımcılar; "Zaman” teması altında \%100'ü geniş zaman aralığında yapılması şeklinde görüş belirtmişlerdir. "İletişim" teması altında \%33.3'ü iletişim kurma, \%33.3'ü açık ve anlaşılır anlatım sergileme ve \%33.3'ü aile ile iletişim kurma şeklinde görüş belirtmişlerdir. "Özel Eğitim Uygulamaları" temas1 altında \%46.8'i etkinlik uygulama, \%36.2'si materyal kullanma, $\% 14.9$ 'u teknik kullanma ve \%2.1'i düzeye uygun BEP ve BÖP hazırlama şeklinde görüş belirtmişlerdir.

K13, K2 ve K5 kodlu öğretmen adayları kaynaştırma öğrencileriyle yaptığınız matematik uygulamalarının daha etkili ve verimli yürütülmesinde öğretmen adayların görüşleri şu ifadelerle açıklamışlardır:

"Daha fazla zaman verilmeli. Öğrencinin ilgileri doğrultusunda kullanılacak materyal seçimine dikkat edilmeli." (K13)

"Bence daha etkili ve verimli olmast için daha geniş bir zaman aralığında yapılmalıdır. Öğrenciyle aramızdaki iletişsimin daha etkili olabilmesi için daha sık periyodlar da olmalıdır." (K2)

"Uygulamaların daha verimli olması için özellikle yaparak yaşayarak öğreniminin gerçekleşeceği etkinlikler düzenlenmelidir." (K5) 
Tablo 13. Göreve Başladığında Sınıfında Bulunan Kaynaştırma Öğrencisine Matematik Öğretmeyi Düşünmesine İlişkin Öğretmen Adayı Görüşleri

\begin{tabular}{llcc}
\hline & & $\mathbf{f}$ & $\boldsymbol{\%}$ \\
\hline Evet/Hayır & Evet & 58 & 100 \\
\hline Öneri & Yoktur & 2 & 100 \\
\hline Ĕ̆itim- & Günlük hayatta ihtiyaç duyulması & 25 & 44.6 \\
Öğretim & Eğitim hakkı & 16 & 28.6 \\
& Kaynaştırma öğrencilerini topluma kazandırma & 5 & 8.9 \\
& Eğitimde firsat eşitliği & 4 & 7.1 \\
& Feda edilecek bireyin olmaması & 2 & 3.6 \\
& Öğrenebileceğini düşündüğ̈̈m için & 1 & 1.8 \\
& İdealleri olan bir eğitimci olduğum için & 1 & 1.8 \\
& Diğger öğrencilerden ayırt etmeme & 1 & 1.8 \\
& Matematik öğretmeni olmam & 1 & 1.8 \\
\hline
\end{tabular}

Tablo 13'e göre öğretmen adaylarının göreve başladığında sınıfında bulunan kaynaştırma öğrencisine onlara matematik öğretmeyi düşünmesi hakkındaki görüşleri; “evet/hayır”, “öneri” ve "eğitim-öğretim” teması olmak üzere üç tema altında toplanmıştır.

"Evet/Hayır" teması altında katılımcıların tamamı "evet" şeklinde görüş belirtmişlerdir. "Öneri" teması altında katılımcıların tamamı öneri belirtmemişlerdir. "Eğitim-Öğretim" teması altında katılımcılar; \%44.6's1 günlük hayatta ihtiyaç duyulması, \%28.6'sı eğitim hakk1, \%8.9'u kaynaştırma öğrencilerini topluma kazandırma, \%7.1'i eğitimde fırsat eşitliği, \%3.6'sı feda edilecek bireyin olmaması, \%1.8'i öğrenilebileceği düşünüldüğü için, \%1.8'i idealleri olan bir eğitimci olduğu için, \%1.8'i diğer öğrencilerden ayırt etmeme ve \%1.8'i matematik öğretmeni olması şeklinde görüş belirtmişlerdir.

K20 ve K23 kodlu katılımcılar göreve başladığında sınıfında kaynaştırma öğrencisi bulunursa onlara matematik öğretmeyi düşünmesi hakkında görüşleri şu ifadelerle açıklamışlardır:

"Evet, öncelikle gözlem yapılır ve ögrenci belirlendikten sonra gün boyunca ne yaptlklarl, sosyal özellikleri, konuşma becerisi gibi özellikler gözlenir daha sonra ilgi özelliklerine göre konular sunulur. Matematikte anlatmadan önce günlük hayatta sorular sorulur. Çünkü hayatın her alanında matematiğin olduğu, günlük hayatı ile ilişkilendirmesi, yorumlaması beklenir." (K20) 
"Tabii ki düşünüyorum. Her çocuk eğitim hakkina sâhip ve öğrenme güçlüğüne olması öğrenemeyeceği anlamina gelmiyor. Ben elimden geleni yapıp ögretmeyi düşünüyorum.” (K23)

\section{Tartışma ve Sonuç}

Bu çalışmada, matematik öğretmeni adaylarının "Özel Eğitim" dersinden beklentilerini ve kaynaştırma eğitiminde matematik uygulamalarına ilişkin kazanımlarını ve süreçte karşılaştıkları problemleri ortaya çıkarmak amaçlanmıştır. Çalışmanın sonuçları da iki bölümden oluşmaktadır. Birinci bölümde öğretmen adaylarının; "Özel Ĕgitim” dersine ilişkin görüşleri, ikinci bölümde ise "Kaynaştırma Ĕgitiminde Matematik Uygulamalarına" ilişkin düşüncelerine ait sonuçlar sırasıyla aşağıda yer almıştır:

\section{Öğretmen Adaylarının; “Özel Eğitim” Dersine İlişkin Görüşlerine Yönelik Elde Edilen Sonuçlar}

Öğretmen adaylarının "Özel Ĕgitim” dersinin amaçlarını; bu dersin kendilerine farkındalık sağlayacağını, özel gereksinimli öğrencileri bulundukları sosyal ve akademik çevreye kazandıracaklarını düşündükleri sonucuna ulaşılmıştır. Altıntaş (2014) çalışmasında, öğretmen adaylarının engelli bireyleri engelsiz bireylerden farklı algıladıklarını, "Özel Eğitim" dersini aldıktan sonra farkındalıklarının arttığı ve bu farkın ortadan kalktığı sonucunu elde etmiştir. Benzer sonuçlar; McLeskey ve ark., (2001), Gözün ve Yıkmış (2004), Shippen ve ark., (2005) ve Güven ve Çevik (2011)'in çalışmalarında da açıkça görülmektedir.

Öğretmen adaylarının “Özel Eğitim” dersinden beklentilerini; özel gereksinimli öğrencilerle iletişime geçebilme, bu öğrencilere yaklaşmayı öğrenme ve topluma kazandırma, öğretmenlik provası yapma olarak sıralamışlardır. Bu sonuç Gözün ve Yıkmış, (2004) katılımcıların özel eğitim konusunda bilgilendirilmenin adayların olumlu tutum sergilemesine yol açtığını ortaya koydukları çalışmayla benzerlik göstermektedir. Katılımcıların \%60'1 "Özel Eğitim” dersinin işleniş sürecine (öğrenme süreci) ve süreçte karşılaştıkları güçlükleri prosedür ile uğraşma, \%40'1 ise okuldaki yönetici ve öğretmenlerden destek görememe şeklinde görüş belirtmişlerdir. Çalışmanın bulgusundan elde edilen bu sonuç Pınar-Sazak ve Yıkmış (2004) çalışmasında da açıkça görülmektedir. Bununla birlikte adayların, özel gereksinimli öğrencilerle iletişim kurma noktasında bir zorlukla karşılaşmadıklarını açıkça 
ifade etmişlerdir.

Katılımcıların "Özel Eğitim" dersinin kendilerine sağladığı faydaları; özel gereksinimli öğrencilerle iletişim kurabildiklerini, özel eğitim konusunda farkındalık kazandıklarını (McLeskey ve ark., 2001) ve dersin kendilerine mesleki deneyim kazandırarak öğretmenlik yeterliliklerine katkıda bulunduklarını düşündükleri ortaya çıkmıştır.

Öğretmen adaylarının tamamı göreve başladıklarında "Özel Eğitim” dersinde öğrendiklerini uygulamayı düşündükleri, özel gereksinimli öğrencilerle empati yaptıkları, topluma uyum sağlayan birey yetiştirmeyi hedefledikleri gibi sonuçlar açığa çıkmıştır.

Öğretmen adaylarının "Özel Eğitim" dersinin etkili ve verimli yürütülmesiyle ilgili olarak ise; \%100'ünün dersin işlenişine yönelik herhangi bir öneride bulunmadıkları, grup çalışması yapılmasını, zaman konusunda ders saatinin artırılmasını, drama tekniğinin kullanılmasını, materyal kullanılmasını, mikro öğretim ve grup çalışması uygulamaları yapılmasını istedikleri açığa çıkmıştır.

\section{Öğretmen Adaylarının Kaynaştırma Eğitiminde Matematik Uy- gulamalarına İlişkin Görüşlerine Yönelik Elde Edilen Sonuçlar}

Öğretmen adaylarının okullarda yapılan matematik uygulamasına gitmeden önce hazırlık merhalelerini; BEP/BÖP, etkinlik, materyal hazırlama ve MKDF kullanma şeklinde sıralamışlardır. Ancak pek çok öğretmenin BEP'i bildikleri ancak BEP hazırlama konusunda yeterli bilgiye sahip olmadıkları ve BEP'i tam olarak uygulayamadıkları (Avcıoğlu, 2011; Çuhadar, 2006; Hacısalihoğlu-Karadeniz, Akar ve Şen, 2015; Kargın, Acarlar ve Sucuoğlu, 2003; Pavri ve Luftig, 2000), ortaya konulan sonuçlar arasındadır. Dolayısıyla bu sonuç çalışmanın sonuçlarıyla örtüşmemektedir. Bu duruma neden olarak da öğretmen adaylarının süreçte aldıkları "Özel Ĕgitim" dersinde, BEP hazırlamayla ilgili yeterince bilgilendirildiklerini düşündürmektedir. BEP; özel gereksinimli öğrenciler için hazırlanmış, süreçte öğrencilerin eğitsel performansına uygun, bireysel gereksinimlerini dikkate alarak plânlanan ve uygulanan (Kamens, 2004; MEB, 2012), bu öğrencilerin eğitsel performanslarını geliştirmek ve bütün öğrencilere uygun öğrenme ortamı düzenleyerek hazırlanan, gerektiğinde düzeltilebilen, değiştirilebilen esnek 
bir programdir (Lytle ve Bordin, 2001; Smith ve Brownell, 1995).

Öğretmen adaylarının kaynaştırma öğrencilerine matematik öğretilebilmesine adayların \%98.2'si 'evet', \%1.8'i 'hayır' şeklinde görüş bildikleri görülmüştür. Aynı sorunun devamında öğretmen adaylarının okullarda yaptıkları uygulamada; "Cebir" ünitesinde 'varlıklar arasındaki ilişkiler' ve 'sayı örüntüleri'; "Sayılar ve İşlemler” ünitesinde 'ritmik saymalar', 'doğal say1larda dört işlem', 'kesirler' ve 'doğal sayılar' olarak sıralamışlardır. "Geometri” ünitesinde 'temel geometrik kavramlar', 'geometrik cisimler', 'üçgen ve dörtgen', 'örüntü' ve 'çokgensel bölgeler'; “Ölçme” ünitesinde 'kütle ölçme', 'paralarımız', 'uzunluk ölçme', 'zaman ölçme', 'alan ölçme' ve 'tartma' konularını öğretmeye çalıştıkları elde edilen sonuçlar arasındadır. Erbaş (2008) çalışmasında, özel gereksinimli öğrencilerin eğitsel performansına ve engel durumuna en uygun yöntemin seçilerek, paranın alış-veriş gibi gündelik hayatın rutin aktivitesinde kullanılmasına yönelik kuramsal ve uygulamalı bilgilere değinmiştir. Bu durum çalışmada adayların özel gereksinimli öğrencilere öğretilebilen ünitelerden, “Ölçme” ünitesinin 'paralarımız' konusunun önemine olan vurguya işaret etmektedir.

Öğretmen adaylarının okullarda yapılan uygulamada kaynaştırma öğrencilerine matematik dersinde; gösterip yaptırma, soru-cevap, anlatım, eğitsel oyun, drama model olma, beyin fırtınası, buluş yolu, sunuş yolu, ipucu verme, tekrar etme, ödüllendirme, modelleme, tartışma, problem çözme ve şiir yöntem/tekniklerini kullandıklarını belirtmişlerdir. Bu duruma neden olarak, öğretmen adayların gerek "Özel Öğretim Yöntemleri-I-II”, gerekse "Özel Ĕgitim" derinlerinde sınıf içi uygulamalarda kullanılan yöntem/teknik uygulamalarının etkili olması gösterilebilir. Oysa Hacısalihoğlu-Karadeniz, Akar ve Şen (2015) çalışmalarında, matematik öğretmenlerinin büyük bir çoğunluğunun kaynaştırma uygulamaları sürecinde öğretmen merkezli bildik yöntemlerle uygulamalar yaptıklarını ortaya koymuşlardır. Bu duruma, öğretmenlerin özel eğitim konusunda hizmet öncesinde ve hizmet içinde yeterince bilgilendirilmemiş olmaları neden olmuş olabilir. Vuran ve Çolak (2007) çalışmalarında, kaynaştırma sınıfı öğretmenlerinin, sosyal beceri ve öğretimine yönelik bilgilerinin yetersiz ve sosyal beceri öğretim tekniklerine ilişkin bilgi düzeylerinin düşük olduğunu ortaya koymuşlardır. Aynı çalışmada, 172 öğretmenden sadece \%2.3 model olma ve ödüllendirme tekniklerine ilişkin soruları; 10 öğretmenin ise \%5.8 ise prova etme tekniğini kullan- 
dıkları sonucuna ulaşmışlardır. Bu durum da, öğretmenlerin yöntem/teknik kullanma konusundaki bilgilerinin yetersiz olduğunu açıkça göstermektedir. Oysaki Meslekî Eğitim ve Öğretim Sisteminin Güçlendirilmesi Projesi [MEGEP] (MEB, 2013)'de model olma ve gösterim (demonstrasyon), ödüllendirme, güdüleme, soru sorma, istenilenlerin tekrar edilmesi, ipucu verme ve çoklu uyaranlar, genişletme, göz kontağı kurma, geri iletim, cümle tamamlama, davranışın sözel ifadesi, küçük grup çalışması, keşfederek-yaparak-yaşayarak öğrenme, buluş yoluyla öğrenme ve örnekleme gibi özel yöntem/tekniklerin kaynaştırma eğitiminde kullanılabileceği belirtilmektedir.

YÖK'ün eğitim fakültelerinin bütün bölümlerine 2006 y1lından sonra “Özel Eğitim” dersini yürürlüğe koyduğunu düşünecek olursak 2006 y1lından önce mezun olan öğretmenlerin bu konudaki bilgilerinin yetersiz olmasının beklenen bir durum olduğu söylenebilir. Babaoğlan ve Yılmaz (2010), Berry (2011), Demir ve Açar (2011), Kayhan, Şengül ve Akmeşe (2012), Hacısalihoğlu-Karadeniz, Akar ve Şen (2015) çalışmalarında elde ettikleri; “öğretmenlerin kaynaştırma uygulamaları ve özel eğitim konusunda bilgilerinin eksik olduğu, yeterli deneyimlerinin olmadĭ̆gl" sonucu da bu durumu destekler niteliktedir.

Öğretmen adaylarının kaynaştırma öğrencileriyle yapılan matematik uygulamasında matematik dersinin işleniş sürecine (öğrenme süreci) ve dersin işleniş sürecinde karşılaşılan güçlükleri; paraları karıştırma, özel eğitim uygulamalarında etkinlik ve materyal hazırlama olarak sıralarken bu öğrencilerle iletişime geçmede herhangi bir güçlükle karşılaşılmadığı sonuçlarına ulaşılmıştır. Çalışmada öğretmen adaylarının uygulama sürecinde materyal kullanmasına karşılık öğretmenlerin pek çoğunun süreçte materyal kullanmadıkları (Hacısalihoğlu-Karadeniz, Akar ve Şen, 2015) ortaya konan sonuçlar arasındadır. Oysa Salend ve Duhaney'in (1999) çalışmalarında, öğretmenlere öğretimsel ve fiziksel kaynaklar, strateji kullanma, zaman, öğretim programı hazırlama ve uygulama, değerlendirmede işbirliği yönünde destek verilmesinin önemli olduğunu vurgulamıştır. Mcleskey ve Waldron'un (2002) çalışmalarında da benzer bulgular ortaya çıkmıştır.

Öğretmen adaylarının kaynaştırma öğrencileri ile yapılan matematik uygulamalarının sağladığı/sağlayacağı faydaları (bireysel, akademik, meslekî 
vb.); etkinlik hazırlama, karşılaşabilecek problemlere çözüm bulma, tecrübe sâhibi olma, sabırlı ve hoşgörülü olma, eksiklerini görme, duyarlı olma, bilgi sâhibi olma, bireysel yönden kazanç sağlama, bireysel farklılığı göz ardı etmeme ve farklı bir bakış açısı kazanma sonuçlarına ulaşılmıştır. Çalışmada elde edilen bu sonuç; öğretmen adaylarının kaynaştırma öğrencisine karşı duyarlı olmayı, uygulamaları gönüllülük esasına dayanarak yürütebilmeyi kabullenecek bir yapıya sâhip olması gerektiğini düşündükleri anlaşılmaktadir (Kargin, 2004; Batu ve Kırcaali-İftar, 2007; Salend ve Duhaney, 1999).

Öğretmen adaylarının kaynaştırma öğrencileriyle yapılan matematik uygulamalarının daha etkili ve verimli yürütülmesini daha geniş zaman aralığında yapılması ve etkinlik hazırlanması elde edilen sonuçlar arasındadır. Blecker ve Boakes (2010), Horne ve Timmons (2009) ve Saraç ve Çolak (2012) çalışmalarında kaynaştırma eğitimine yeterli zaman ayıramadıkları sonucuyla paralellik göstermektedir.

Öğretmen adaylarının tamamı göreve başladığında sınıfında kaynaştırma öğrencisi bulunduğunda onlara matematik öğretmeyi düşündüklerini, kaynaştırma öğrencilerini topluma kazandırma, eğitim hakkı ve eğitimde firsat eşitliği, feda edilecek bireyin olmaması, öğrenebileceklerini düşünmesi, idealleri olan bir eğitimci olması, diğer öğrencilerden ayırt etmemesi şeklinde görüş bildirdikleri ortaya çıkmıştır. Shippen ve diğerlerinin (2005) çalışmasında, özel gereksinimli öğrencilere sosyal becerileri kazandırmanın yanı sıra akademik becerilerini geliştirmeyi daha iyi algıladıkları sonucuyla örtüşmektedir.

Özetle bulgulardan elde edilen sonuçlara göre; “Özel Eğitim” dersinin, bir süre sonra göreve başlayacak öğretmen adaylarına olumlu katkıları olduğu ve kaynaştırma eğitiminde matematik uygulamalarına ilişkinse; öğrenci ve aileleriyle iletişim kurmayı, sabırlı, hoşgörülü ve duyarlı olmayı sağladığı ortaya çıkmıştır. Ayrıca kaynaştırma eğitiminde matematik uygulamalarında etkinlik uygulama, materyal kullanma, çeşitli öğretim yöntem/teknikleri kullanma ve eğitsel performanslarına uygun BEP ve BÖP hazırlanmasının yaranına olan vurgudur. Katılımcıların tamamına yakını bu dersin; özel gereksinimli öğrenci ve kaynaştırma uygulamalarının yapısının kavranmasında kolaylık sağladığı, bu tür çocuklara yönelik farkındalıklarının ve hassasiyetlerinin arttığı, çok faydalanacakları bilişsel ve duyuşsal yeni öğrenmeler elde 
ettikleri ve bu öğrendiklerinin kendilerine meslekî deneyim kazandırarak öğretmenlik yeterliliklerine katkıda bulunduğunu düşündükleri ortaya çıkmıştır. Ayrıca adayların pek çoğu "Özel Eğitim" dersini kuramsal bilgi edinmenin yanı sıra, özel gereksinimli öğrencilerle matematik uygulamalarını yapmaktan büyük bir memnuniyet duydukları ifade etmişlerdir.

\section{Öneriler}

Türkiye'de güncellenen ortaokul matematik öğretim programı ve ders kitaplarında da konu ya da kazanımların öğretiminin etkinliler yoluyla gerçekleştirilmesine vurgu yapılmaktadır (MEB, 2013). Benzer biçimde Amerika'daki Matematik Öğretmenleri Ulusal Konseyi de etkinlik uygulamalarıyla öğrenciyi merkeze alan matematik öğretimine dikkat çekmektedir (National Council of Teachers of Mathematics [NCTM], 2000). MKDF'de yer alan öğretimsel amaçlar belirlenerek özel gereksinimli öğrencilerin eğitsel performanslarına uygun etkinlikler geliştirilerek matematik öğretilebilir. Böylece onların düzeyine uygun, temel ihtiyaçlarını gidermeye yardımcı olacak, gündelik hayatlarının akışını rahatlatacak ve belki bir meslek sahibi olmayı kolaylaştıracak kadar matematik becerisi kazandırmak mümkün olabilir.

Matematik öğretmenliği programından mezun olan öğretmen adaylarının büyük bir kısmı, mesleğe başladıklarında özel gereksinimli öğrencilerle karşılaşmakta ve bu konuda yeterli eğitimi almamış olmalarının eksikliğini hissetmekte ve BEP hazırlamakta zorlanmaktadırlar (Avcıŏlu, 2011; Çuhadar, 2006; Hacısalihoğlu-Karadeniz, Akar ve Şen (2015); Kargın, Acarlar ve Sucuoğlu, 2003). Bununla birlikte YÖK'ün eitim fakültelerinin bütün bölümlerine 2006 yılından itibaren "Özel Ĕgitim" dersini yürürlüğe koyduğunu düşünecek olursak öğretmen adaylarına kaynaştırma uygulaması ile ilgili olarak bu ders kapsamında bilgiler verilmektedir. Ancak öğretmen adaylarına kuramsal bilginin dışında matematik dersinde yapılabilecek öğretimsel düzenlemeler ile ilgili olarak herhangi bir eğitim verilmemektedir. Bu çalışmada matematik öğretmeni adaylarının "Özel Eğitim" dersinden beklentileri ve kaynaştırma eğitiminde matematik uygulamalarına ilişkin kazanımları ve süreçte karşılaştıkları problemler ortaya konmuştur. Dolayısıyla matematik öğretmeni adaylarına, matematik öğretmenlerine ve bu dersi yürüten öğretim elemanlarına faydalı olabilecek bir takım öneriler geliştirilmiştir: 
$\checkmark$ Matematik Eğitimi ABD’de yürütülen "Özel Öğretim Yöntemleri” derslerinde, özel gereksinimli öğrencilerinin kaynaştırma eğitiminde matematik uygulamalarına yer verilmelidir.

$\checkmark$ "Okul Deneyimi” ve "Öğretmenlik Uygulaması" dersleri çerçevesinde öğretmen adaylarının kaynaştırma öğrencilerinin bulunduğu okullarda deneyim yaşaması sağlanmalıdır.

$\checkmark$ Matematik öğretmeni adaylarının, özel eğitim derslerinde soru-cevap, beyin firtınası, oyun, drama, işbirlikli öğrenme, gösteri, gösterip yaptırma, keşfetme, kâğıt katlama yöntem ile matematik öğretimi gibi yöntem/teknikleri kullanmaya alıştırılmaları sağlanabilir.

$\checkmark$ Okullardaki müdür, rehber öğretmen, sınıf öğretmeni ve özel eğitim öğretmeni uygulamalarda öğretmen adaylarına yardımcı olmalı, resmi prosedürlerle adaylara engeller çıkartmamasına özen gösterilmeli, uygulamalarda destek eğitim odalarında çalışabilmelerine yardımcı olunmalıdır.

$\checkmark$ Kaynaştırma uygulamalarında matematik öğretiminde kullanılabilecek somut nesne, araç-gereç ve materyallerden yararlanılmasına dikkat çekilebilir

$\checkmark$ Eğitim fakültelerinin "Matematik ve Fen Bilimleri Eğitimi” bölümünde öğrenim gören öğretmen adaylarının öğretmenlik meslek bilgisi derslerinden biri olan "Özel Eğitim” dersinin içeriğine kaynaştırma eğitimi uygulamaları ile ilgili bilgiler serpiştirilerek farkındal1kları artırılabilir, matematik ve fen eğitimi uygulamalarına yönelik eğitimler almaları sağlanabilir. Ayrıca adayların bu tür öğrencilerle karşılaştıklarında nasıl bir öğrenme ortamı tasarlayacaklarına ve öğrenme-öğretme süreci izleyeceklerine yönelik matematik etkinlikleri hazırlanabilir.

\section{Kaynakça}

Altıntaş, E. (2014). Özel eğitim dersinin kaynaştırmaya yönelik tutumlar ve kazanımlar bakımından değerlendirilmesi. Kafkas Üniversitesi, e-Kafkas Ĕgitim Araştırmaları Dergisi, 1(3), 1-12. 
Alptekin, S. (2015). Sayma becerilerinin öğretimi. Ankara Üniversitesi Eğitim Bilimleri Fakültesi Özel Ĕgitim Dergisi, 16(1), 63-72.

Avcıoğlu, H. (2011). Zihin engelliler sınıf öğretmenlerinin bireyselleştirilmiş eğitim programı (BEP) hazırlamaya ilişkin görüşleri. Ankara Üniversitesi Ĕ̌itim Bilimleri Fakültesi Özel Ĕgitim Dergisi, 12(1), 39-53.

Babaoğlan, E. ve Yılmaz, Ş. (2010). Sınıf öğretmenlerinin kaynaştırma eğitimindeki yeterlilikleri. Kastamonu Eğitim Dergisi, 18(2), 345-354.

Batu, E. S. (2000). Kaynaştırma destek hizmetler ve kaynaştırmaya hazırlık etkinlikleri. Özel Ĕ̈itim Dergisi, 2(4), 35-45.

Batu, S. (2008). Kaynaştırma ve destek özel eğitim hizmetleri. İ. H. Diken (Ed.), Özel eğitim içinde (89-107). Ankara: Pegem Yayınc1lık.

Batu, S. ve Kırcaali-İftar, G. (2007). Kaynaştırma. Ankara: Kök Yayıncılık.

Batu, S., Kırcaali-İftar, G. ve Uzuner, Y. (2004). Özel gereksinimli öğrencilerin kaynaştırıldığ bir kız meslek lisesindeki öğretmenlerin kaynaştırmaya ilişkin görüş ve önerileri. Ankara Üniversitesi Eğitim Bilimleri Fakültesi Özel Ĕ̈itim Dergisi, 5, 33-50.

Berry, R. A. W. (2011). Voices of experience: General education teachers on teaching students with disabilities. International Journal of Inclusive Education, 15, 627-648.

Blecker, N. ve Boakes, N. (2010). Creating a learning environment for all children: Are teachers ableand willing? International Journal of Inclusive Education, 14(5), 435-447.

Bogdan, R. C. ve Biklen, S. K. (2003). Qualitative research for education: An introduction to theories and methods (4. bask1). New York, NY: Pearson education group.

Çuhadar, Y. (2006). İlköğretim okulu 1-5. sinıflarda kaynaştırma eğitimine tabi olan ögrenciler için bireysel eğitim programlarının hazırlanmasl, uygulanması, izlenmesi ve değerlendirilmesi ile ilgili olarak sinıf öğ- 
retmenleri ve yöneticilerin görüşlerinin belirlenmesi. Yayımlanmamış yüksek lisans tezi, Karaelmas Üniversitesi, Eğitim Bilimleri Enstitüsü.

Demir, M. K. ve Açar, S. (2011). Kaynaştırma eğitimi konusunda tecrübeli sınıf öğretmenlerinin görüşleri. Kastamonu Eğitim Dergisi, 19, 719-732.

Denzin, N. K. ve Lincoln, Y. S. (2000). Introduction: The discipline and practice of qualitative Research. N. K. Denzin ve Y. S. Lincoln (Eds.), Handbook of Qualitative Research içinde (1-28). Thousand Oaks, CA: Sage Publications.

Diken, İ. H. (1998). Sinıfinda zihinsel engelli çocuk bulunan ve bulunmayan sınıf öğretmenlerinin zihinsel engelli çocukların kaynaştırılmasına yönelik tutumlarının karşılaştırılması. Yayımlanmamış yüksek lisans tezi, Abant İzzet Baysal Üniversitesi, Sosyal Bilimler Enstitüsü.

Erbaş, D. (2008). Özel gereksinimli öğrencilere genel para kullanımını öğretme. Ankara Üniversitesi Ĕ̈itim Bilimleri Fakültesi Özel Ĕ̈̆itim Dergisi, 9(1), 35-52.

Gözün, Ö. ve Yıkmış, A. (2004). Öğretmen adaylarının kaynaştırma konusunda bilgilendirilmelerinin kaynaştırmaya yönelik tutumlarının değişimindeki etkililiği. Ankara Üniversitesi Eğitim Bilimleri Fakültesi Özel Eğitim Dergisi, 5(2), 65-77.

Gürgür, H. (2008). Kaynaştırma uygulamasının yapıldığı ilköğretim sınıfında iş birliği ile öğretim yaklaşımının incelenmesi. Eskişehir: Anadolu Üniversitesi Yayınları.

Güven, E. ve Çevik, D. B. (2011, Nisan). Müzik öğretmeni adaylarının kaynaştırmaya ilişkin görüşlerinin belirlenmesine yönelik bir çalışma (Balıkesir Üniversitesi Örneği). $2^{\text {nd }}$ International Conference on New Trends in Education and Their Implications, Antalya, Türkiye.

Hacısalihoğlu-Karadeniz, M. (2013). Diskalkuli yaşayan öğrencilere ilişkin öğretmen görüşlerinin değerlendirilmesi. e-Journal of New World Sciences Academy Social Sciences, NWSA, 8(2), 439-450. 
Hacısalihoğlu-Karadeniz, M., Akar, Ü. ve Şen, H. (2015). Kaynaştırma eğitimi süreci: Sınıf içi matematik uygulamaları. Milli Eğitim Dergisi, 207, 169-188.

Horne, P. E. ve Timmons, V. (2009). Making it work: Teachers' perspectives on inclusion. International Journal of Inclusive Education, 13(3), 273-286.

Hudson, P. ve Miller, S. P. (2006). Designing and implementing mathematics instruction for students with diverse leaming needs. Boston: Pearson Education Inc.

Kamens, M. W. (2004). Learning to write IEPs: A personalized, reflective approach for preservice teachers. Intervention in School and Clinic, 40(2), 76-80.

Kargın, T., Acarlar, F. ve Sucuoğlu, B. (2003). Öğretmen, yönetici ve anne-babaların kaynaştırma uygulamalarına ilişkin görüşlerinin belirlenmesi. Ankara Üniversitesi Eğitim Bilimleri Fakültesi Özel Eğitim Dergisi, 4, 55-76.

Kargın, T. (2004). Kaynaştırma: Tanımı, gelişimi ve ilkeleri. Ankara Üniversitesi Ĕ̆itim Bilimleri Fakültesi Özel Ĕ̆itim Dergisi, 5(2), 1-13.

Kayhan, N., Şengül, A. ve Akmeşe, A. A. (2012). İlköğretim birinci ve ikinci kademe öğretmen adaylarının kaynaştırmaya ilişkin görüşlerinin incelenmesi. Journal of Research in Education and Teaching, 1(3), 268-278.

Kırcaali-İftar, G. (1997). Özel eğitimde kaynaştırma. Anadolu Üniversitesi Eğitim Fakültesi Dergisi, 16, 45-49.

Lytle, R. ve Bordin, J. (2001). Enhancing the IEP team, strategies for parents and professionals. Teaching Exceptional Children, 33(5), 40-44.

Maag, J. W. (2005). Social skills training for youth with emotional and behavioral disorders and learning disabilities: Problems, conclusions, and suggestions. Exceptionality, 13, 155-172. 
McLeskey, J., Waldron, N. L., So, T., Swanson, K. ve Loveland, T. (2001). Perspectives of teachers toward inclusive school programs. Teacher Education and Special Education (TESE), 24(2), 108-115.

McLeskey, J. ve Waldron, N. L. (2002). Inclusion and school change: Teacher perceptions regarding curricular and instructional adaptations. Teacher Education and Special Education, 25, 41-54.

Milli Eğitim Bakanlığı. (1997). Özel eğitim hakkında kanun hükmünde kararname. http://orgm.meb.gov.tr/Mevzuat/573.htm.

Milli Eğitim Bakanlığı. (2000). Özel eğitim hizmetleri yönetmeliği. http://orgm.meb.gov.tr/Mevzuat/ozel_yon_SON/ozelegitimyonetmelik SON.htm.

Milli Eğitim Bakanlığı. (2006). Özel Eğitim Hizmetleri Yönetmeliği. http://orgm.meb.gov.tr/Mevzuat/ozel_yon_SON/ozelegitimyonetmelik SON.htm.

Milli Eğitim Bakanlığı. (2008). Özel Eğitim ve Rehabilitasyon Merkezi Zihinsel Engelli Bireyler, Destek Eğitim Programı. https://ookgm.meb.gov.tr/meb_iys_dosyalar/2014_02/14114042_zede p.pdf.

Milli Eğitim Bakanlığı. (2012). Özel Eğitim Hizmetleri Tanıtım El Kitabı. Ankara: Milli Eğitim Basımevi.

Milli Eğitim Bakanlığı. (2013). Mesleki Eğitim ve Öğretim Sisteminin Güçlendirilmesi Projesi (MEGEP). Çocuk Gelişimi ve Eğitimi Kaynaştırma Eğitimi. Ankara: Milli Eğitim Basımevi.

National Council of Teachers of Mathematics. NCTM. (2000). Principles and standards for school mathematics. Virginia.

Özokçu, O. (2013). Kaynaştırma uygulamaları. S. Vuran (Ed.), Özel eğitim içinde (81-111). Ankara: Maya Akademi. 
Patton, Q. M. (2002). Practical Evaluation. Thousand Oaks, CA: Sage Publications.

Pavri, S. ve Luftig, R. (2000). The social face of inclusive education: Are students with learning disabilities really included in the classroom? Preventing School Failure, 45, 8-14.

Pınar-Sazak, E. ve Yıkmış, A. (2004, Kasım). İlkokul müdürlerinin kaynaştırma uygulamasına yönelik görüşlerinin belirlenmesi, 14. Ulusal Özel Eğitim Kongresi'nde sunulan bildiri, Bolu.

Salend, S. J. ve Duhaney, L. M. G. (1999). The impact of inclusion on students with and without disabilities and their educators. Remedial and Special Education, 20, 114-126.

Saraç, T. ve Çolak, A. (2012). Kaynaştırma uygulamaları sürecinde ilköğretim sınıf öğretmenlerinin karşlaştıkları sorunlara ilişkin görüş ve önerileri. Mersin Üniversitesi Ĕ̈itim Fakültesi Dergisi, 8(1), 13-28.

Sazak-Pınar, E., Sucuoğlu, B. ve Çıkrıkçı-Demirtaşlı, N. (2013). Identifying of knowledge levels of classroom teachers who have students with special needs in their classrooms about teaching social skills. Education and Science, 38(168), 230-244.

Shippen, M. E., Crites, S. A., Houchins, D. E., Ramsey, M. L. ve Simon, M. (2005). Preservice teachers' perceptions of including students with disabilities. Teacher Education and Special Education (TESE), 28(2), 92-99.

Smith, S. W. ve Brownell, M. T. (1995). Individualized education programs: Considering the broad context for reform. Focus on Exceptional Children, 28(1), 1-12.

Smith, T. E. C., Polloway, E. A., Patton, J. R. ve Dowdy, C. A. (2006). Teaching students with special needs in inclusive settings (Revised IDEA edition). Boston: Allyn \& Bacon.

Stake, R. E. (1995). The art of case study research. Thousand Oaks, CA: SAGE Publications. 
Sucuoğlu, B. (2004). Türkiye'de kaynaştırma uygulamaları: Yayınlar/araştırmalar. Ankara Üniversitesi Eğitim Bilimleri Fakültesi Özel Ĕ̈itim Dergisi, 4, 55-76.

Sucuoğlu, B. ve Kargın, T. (2006). İlköğretimde kaynaştırma uygulamaları: yaklaşımlar, yöntemler, teknikler. İstanbul: Morpa Kültür Yayınları.

Vuran, S. ve Çolak, A. (2007, Kasım). İlköğretim kaynaştırma sınıfı öğretmenlerinin kaynaştırmaya ve sosyal beceri öğretimine ilişkin görüşleri. 17. Ulusal Özel Eğitim Kongresi'nde sunulan bildiri. Çeşme, İzmir.

Yıldırım, A. ve Şimşek, H. (2011). Sosyal bilimlerde nitel araştırma yöntemleri. Ankara: Seçkin Yayıncılık.

Yönter, S. (2009). İlköğretim kaynaştırma sinıfi öğretmenlerinin zihinsel yetersizliği olan ögrencilere yönelik matematik ögretimi uyarlamalarına ilişkin görüşleri. Yayımlanmamış yüksek lisans tezi, Anadolu Üniversitesi, Eğitim Bilimleri Enstitüsü. 